\title{
Jaguares de nuevo. Consideraciones SOBRE LA TEMÁTICA FELÍNICA EN LA iconografía CERÁmica del Período Tardío en Yocavil（Noroeste Argentino)
}

Alejandra Reynoso y Gerónimo Pratolongo ${ }^{1}$

\begin{abstract}
Resumen
La figura del felino, la del jaguar principalmente, tuvo un gran protagonismo en la iconografía de las sociedades andinas desde hace por lo menos 4000 años. Muchas veces se ha postulado una continuidad histórica en las representaciones felínicas como consecuencia a su vez de una continuidad en las ideas religiosas asociadas a dicha temática. Este trabajo se basa en el estudio de las representaciones de jaguares que se despliegan en la cerámica del PeríodoTardío en el valle de Yocavil, estilo conocido como santamariano. Así, vemos que la figura del felino desaparece del repertorio iconográfico de la región a fines de 1000 DC, es decir, desde el inicio del Período Tardío y reaparece luego, aproximadamente cuatro siglos después, en los momentos finales de dicho período. Finalmente, planteamos algunas ideas para discutir esta discontinuidad en la presencia de la temática felínica en Yocavil.
\end{abstract}

Palabras claves: iconografía - cerámica - felino - Período Tardío Yocavil - Noroeste Argentino.

\footnotetext{
Abstract

The feline figure - mainly that of the jaguar- was central to the iconography of Andean societies for 4000 years. It has often been suggested that this continuity of felinic representations corresponds to that of religious ideas. The Late Period jaguar representations in Yocavil

Valley pottery (Santamariano style) disappears from the regional iconographic repertory towards the end of the first millennium of our era (early Late Period), only reappearing four centuries later. Our conclusion addresses the discontinuity of the feline topic in Yocavil.

$$
\begin{array}{r}
\text { Key words: iconography - pottery - feline - Late Period - } \\
\text { Yocavil - Northwest Argentina. }
\end{array}
$$$$
\text { Recibido: abril 2007. Aceptado: noviembre 2007. }
$$

\section{- Iconografía y poder: El jaguar en las socie- DADES ANDINAS}

El jaguar, animal misterioso e imponente de las selvas americanas, ha llegado adonde nunca se hubiera imaginado. Su representación tuvo un gran protagonismo en la iconografía de las sociedades andinas desde hace por lo menos cuatro mil años. El jaguar y en general las imágenes del denominado "complejo felínico" reflejan para muchos investigadores ideas básicas que permanecen durante un amplio lapso temporal iniciado mucho antes de Chavín y que se extiende hasta la época de los incas (González 1998:181). No obstante, si enfocamos nuestra atención en distintas historias regionales encontramos discontinuidades en algunas de ellas. En esta oportunidad nos centraremos en las representaciones felínicas plasmadas en la iconografía de la cerámica producida por las sociedades del Período Tardío en el valle de Yocavil (Noroeste Argentino) ${ }^{2}$, cuyo estilo es conocido como "Santa María" o "santamariano".

Un aspecto importante del estudio de la iconografía de las sociedades pasadas radica en que esta constituye, entre otras posibilidades, una puerta para el conocimiento de la ideología religiosa y, por ende, de una de las instancias de producción y reproducción de las relaciones sociales. La religión pertenece al ámbito de lo sagrado entendiendo por ello un cierto tipo de relación con los orígenes en la

\footnotetext{
1 Museo Etnográfico “Juan B. Ambrosetti”, Facultad de Filosofía y Letras, Universidad de Buenos Aires. Moreno 350 (1091), Buenos Aires, ARGENTINA.Email: ad_reynoso@yahoo.com.ar; geprato@hotmail.com

2 Período inmediatamente anterior a la expansión incaica. Coincide con el Período Intermedio Tardío para los Andes Centrales, Centro-Sur y Chile.
} 
que, en lugar de los seres humanos reales, se instalan dobles imaginarios de estos pero más poderosos: los antepasados y los dioses (Godelier 1998: 245). Esta relación (imaginaria) con los orígenes de la sociedad, es decir, con los antepasados y los dioses, es una relación jerárquica, ya que ellos son conceptualizados como entidades superiores a los seres humanos por haberles legado la existencia (en el caso de los dioses), el territorio, los animales y plantas domesticadas así como el conocimiento para fabricar herramientas (en el caso de los antepasados).

Lo sagrado, así definido, se constituye en la parte religiosa del poder social (Godelier 1998: 243). De esta manera, en sociedades donde existe algún tipo de jerarquía o estratificación entre los individuos, los géneros o entre los grupos que la conforman, la religión proporciona el marco conceptual para la naturalización (sacralización) de dichas relaciones asimétricas, esto es, las relaciones jerárquicas entre los seres humanos y los dioses como paradigma de las relaciones jerárquicas entre los estamentos que constituyen la sociedad. Un individuo o grupo que pretende imponerse sobre sus pares, al buscar emparentarse con los dioses o con los antepasados y así apropiarse de las condiciones imaginarias de reproducción de la vida y de la sociedad (Godelier 1998:274) intenta legitimar esa relación de imposición sacralizándola.

En arqueología, la problemática religiosa se ha abordado principalmente a través de la iconografía, ya que esta constituye claramente una instancia para la comunicación social. Así, el estudio de las representaciones gráficas que fueron plasmadas en la cerámica, la piedra, los tejidos o cualquier otro soporte material, permite una aproximación a diversos aspectos de las relaciones sociales pasadas. En este caso se destacan las imágenes del jaguar, uno de los grandes protagonistas del mundo religioso andino y que también lo será en nuestro análisis iconográfico de la cerámica santamariana.

Si bien nos centraremos en las representaciones de jaguares, muchas veces nos referiremos genéricamente a ellas como "tema felínico". A lo largo de la historia precolombina de las sociedades andinas el tema felínico se manifiesta de distintas maneras encarnándose en especies reconocibles o no, fieles a la realidad o constituidas a pesar de esa misma realidad. Así, por ejemplo, el felino de Chavín es un jaguar, el de Tiwanaku mayoritariamente un puma (González 1998: 172), en numerosas vasijas Moche el felino es un jaguar (Benson 1974) y sabemos que en el mundo simbólico incaico el puma y el jaguar ocupan un lugar protagónico (Zuidema 1989; Farrington $2001 \mathrm{Ms}$ ). Mientras que al mismo tiempo existen representaciones en las cuales se combinan otros elementos o se alteran ciertas realidades, pero en donde siempre se destaca el carácter felínico dado por atributos reconocibles, como por ejemplo las fauces con prominentes colmillos o las afiladas garras y, en algunos casos, manchas en el pelaje. Salvo en casos puntuales donde resulte importante discutir la relevancia simbólica y en interacción de las distintas especies (como por ejemplo en el caso incaico), sea jaguar, ocelote, puma o una combinación indefinible, lo importante es la idea, el sentido asociado a "lo felínico" que se intenta comunicar a través de estas imágenes religiosas.

Los primeros indicios del tema felínico en los Andes se observan a partir del hallazgo en el valle de Pativilca (Costa Central de Perú) de un fragmento de calabaza grabada, fechado alrededor de $2200 \mathrm{AC}$, el cual muestra un personaje con rostro felínico sosteniendo en sus manos dos cetros (Haas y Creamer 2004: 48, Fig. 3.2). Aunque es en Chavín alrededor de 1000 AC en los Andes Centrales cuando se despliega fuertemente el denominado "complejo felínico" (González 1998:169). Posteriormente, las imágenes felínicas continuaron marcando la historia de las sociedades andinas. En el Noroeste Argentino la imagen del felino ha sido profusamente representada por sociedades del Período Temprano (Condorhuasi, Ciénaga). En Aguada (siglos VII a X, aproximadamente) las imágenes del jaguar serán protagonistas de sus distintas manifestaciones plásticas, que junto a otros motivos característicos como el sacrificador, el anfisbena y el personaje de los dos cetros, conformarán el "complejo felínico" (González 1998).

Dentro de la iconografía andina, en general este felino está asociado a un personaje antropomorfo (aunque 
también puede ser otro animal, como la serpiente o la llama) que representaría a la deidad o al propiciador de los rituales de carácter religioso (González 1992, 1998). Por sus características estos personajes son claramente intimidatorios, portan hachas, cabezas humanas cercenadas, máscaras y/o pieles felínicas y muchas veces se los representa sacrificando seres humanos.

Si tenemos en cuenta el carácter jerarquizado o estratificado de las sociedades en donde se manifiesta el "complejo felínico"3, las escenas intimidantes vinculadas a dicho complejo se nos aparecen como una instancia de legitimación del orden social jerárquico. Esta legitimación pasa por la demostración de fuerza del oficiante del rito, ya sea por su vinculación con las fuerzas sobrenaturales (es decir su sacralidad) como por su capacidad de sacrificar personas.

Una gran parte de la iconografía felínica de las sociedades agropastoriles andinas precolombinas parecen remitir a estas dos instancias antes mencionadas: el consentimiento y la violencia. El consentimiento de una relación de dominación depende de la producción de representaciones compartidas que definan dicha relación como un intercambio de servicios entre dominados y dominadores (Godelier 1989: 11-12). No obstante esto, la violencia potencial o efectiva está siempre presente para hacer frente a los conflictos que las representaciones compartidas no logran neutralizar. En el ritual religioso las élites se proponen como intermediarias entre los seres humanos comunes y los dioses o los antepasados. La acción del oficiante religioso se presenta como una actividad necesaria para la producción y reproducción de la vida, sin embargo, una serie de signos que remiten a la violencia (en las imágenes del "complejo felínico" esto es especialmente claro) ponen de manifiesto que lo que hay en la base de esas relaciones sociales no son actividades complementarias y necesarias para la existencia y el bien común, sino un orden social desigual que se busca perpetuar mediante el consenso y la fuerza.

\footnotetext{
3 Ver, por ejemplo, los casos estudiados por Burger (1992), Castillo (1993), Cook (1994) y González (1998).
}

Teniendo en cuenta la importancia de las imágenes del jaguar, en tanto iconografía del poder, para la producción y reproducción de las relaciones sociales dentro de estas poblaciones, lo significativo es su desaparición del repertorio iconográfico de las sociedades precolombinas del Período Tardío del N.O.A. (aproximadamente desde el siglo X DC) y su reaparición en los momentos finales del mismo en Yocavil asociados a la ocupación incaica en la región.

Distintos trabajos mencionan la desaparición del motivo felínico luego del final de Aguada (Kusch y Valko 1999: 111), o bien su continuidad atomizada sólo reconocible en algunas representaciones combinadas plasmadas en los estilos del Período Tardío, más específicamente en las vasijas santamarianas (Kusch 1990: 19; Fiadone 1999). En este trabajo proponemos e intentaremos demostrar que estas dos posibilidades no son verdaderamente incompatibles. Esta aparente contradicción no es tal si tenemos en cuenta la propia historia del estilo santamariano, cuya producción, principalmente de pucos y vasijas funerarias antropomorfas, se desarrolla a lo largo de aproximadamente 500 años. La contradicción se desdibuja si historizamos el estilo y hacemos énfasis en sus variaciones en tiempo y espacio. Tomando como base distintos estudios que tuvieron como objetivo precisamente delinear y discutir la historia del estilo santamariano (Podestá y Perrotta 1973; Perrotta y Podestá 1974 Ms, 1978; Weber 1978), sostenemos la ausencia del motivo felínico (ausencia que se manifiesta como desaparición si tenemos en cuenta la historia previa) durante aproximadamente 400 años para reaparecer luego en algunas vasijas de los últimos tiempos precolombinos de Yocavil. Este trabajo intentará aportar elementos para el sustento de estos puntos y a su vez discutirá sus implicancias.

Si bien más adelante se verá detalladamente esta cuestión, es importante destacar que indudablemente las imágenes felínicas tardías están basadas en un modo de representación diferente a aquellas previas plasmadas en el estilo Aguada. Así, la mayoría de las representaciones santamarianas nos muestran, como bien marcaba Kusch (1990: 19), jaguares combinados con otros animales como el suri o la llama. En cualquier caso, la relevancia 
está dada por la presencia indiscutible de los atributos característicos del jaguar: las manchas del pelaje, las garras, las fauces y la cola. Recordemos que aún en muchas vasijas Aguada, estilo cuya primacía del jaguar nadie discutiría, son estas partes (todas o alguna de ellas) las que definen, más que la totalidad, el tema representado y que también en este estilo desde ya son muy numerosos los ejemplos de representaciones de especies combinadas (hombrejaguar, serpiente-jaguar, camélido-jaguar, mono-jaguar). En definitiva, que en las vasijas santamarianas el jaguar se manifieste combinado con atributos de otras especies no significa que su presencia en la iconografía pueda pasarse por alto.

\section{* El Período Tardío en Yocavil}

Aproximadamente a partir del siglo $\mathrm{X}$ en la región de Yocavil (actuales provincias de Catamarca, Tucumán y Salta) comienzan a desarrollarse nuevas formas de organización social que impulsan la concentración y el crecimiento demográfico y fundamentalmente la reorganización de la producción tendiente a incrementar los excedentes. Dichas formas de organización social implicaron el poder creciente y en confrontación de los jefes políticos y religiosos de las distintas comunidades de la región. Esto se manifiesta en el establecimiento de núcleos residenciales conglomerados en cerros, sus laderas y planicies circundantes, como los asentamientos de Tolombón, Pichao, Quilmes, La Ventanita y El Calvario de Fuerte Quemado, Las Mojarras, Rincón Chico y Cerro Mendocino en el sector occidental del valle y los conjuntos de Yasyamayo, Amaicha, Los Cardones, Masao-Caspinchango, Loma Rica de Jujuil, Loma Rica de Shiquimil, Ampajango y Pajanguillo sobre el margen oriental del valle.

En las sociedades del Noroeste Argentino previas al Período Tardío, y sobre todo en aquellas vinculadas a la cultura de La Aguada, como vimos, la figura del felino y más específicamente del jaguar, tuvo un destacado protagonismo iconográfico y una gran variación en su modo de representación en las distintas regiones como Hualfín, Ambato, Portezuelo y norte de la Rioja (González 1998; Kusch y Abal 2000).
Si bien las investigaciones en torno a Aguada en el valle de Yocavil se encuentran menos desarrolladas que aquellas realizadas en otras regiones más al sur, existen evidencias para sostener que esta zona formó parte del fenómeno macrorregional denominado Aguada. Dichas evidencias provienen tanto de objetos recuperados en distintas localidades del valle e ilustrados en la bibliografía de los primeros estudiosos (p.e., Ambrosetti 1896-1899; Lafone Quevedo 1908) como así también de muestras recuperadas en investigaciones de las últimas décadas (p.e., Raffino et al. 1979-1982; Tarragó et al. 1988 Ms; Tarragó y Scattolin 1999; Tartusi y Núñez Regueiro 2000; Williams 2003; Nastri et al 2004 Ms).

Dentro del repertorio de la cerámica Aguada de Yocavil, y teniendo en cuenta las categorías temáticas propuestas para este estilo por González y Baldini (1991), se pueden observar las representaciones del jaguar serpentiforme $e^{4}$, del motivo antropo-felínico ${ }^{5}$, del motivo jaguar ${ }^{6}$, del tema cabeza central con ornamentación ${ }^{7}$, y del tema antropomorfo con armas. ${ }^{8}$ Aunque hasta el momento lo más frecuente son los hallazgos cerámicos superficiales de la modalidad regional pintada del estilo Aguada denominada en su momento "Guachipas policromo" (Serrano 1967: 29), donde el felino se representa de manera muy abstracta a partir de las fauces, las garras y las manchas. 9

Lo que queremos enfatizar en este trabajo es que las representaciones felínicas, de larga data en las sociedades

\footnotetext{
4 Ver, por ejemplo, Lafone Quevedo (1908:367, Fig. 41), González (1998: 232, Fig. 208), Serrano (1966: Lám. XXVIII.2) y la pieza $\mathrm{n}^{\circ} 36984$, procedente de San José y depositada en el Museo Etnográfico "Juan B. Ambrosetti".

5 Ver Ambrosetti (1896-99: Fig. 56). Se trata de la pieza nº 12411 del Museo Etnográfico "Juan B. Ambrosetti”.

6 Ver Lafone Quevedo (1908: Planchas Vy VI).

7 Ver (Lafone Quevedo 1908: Plancha VII.a).

${ }^{8}$ Ver Tarragó y Scattolin (1999: 147, Fig. 2.e). Este tema se observa en un fragmento de cerámica con decoración grabada, cuyo reducido tamaño no permite determinar si se trata del motivo "personaje de los dos cetros", "personaje con máscara felínica" o "personaje del sacrificador", según las variantes definidas por González y Baldini (1991).

9 Un claro ejemplo sería el puco procedente de Tolombón ya mencionado para la representación del jaguar serpentiforme por González (1998: 232, Fig. 208). Corresponde a la pieza n ${ }^{\circ} 22009$ del Museo Etnográfico "Juan B. Ambrosetti".
} 
andinas, y presentes en Yocavil al menos desde mediados del primer siglo de la era, no forman parte del repertorio iconográfico de las sociedades que se desarrollan en esta región a partir del siglo $X$, aproximadamente, hasta que dichas imágenes reaparecen 400 años después en un contexto contemporáneo a la presencia incaica. Este hecho se pone de manifiesto claramente en las seriaciones de las vasijas santamarianas (variedad Yocavil) realizadas en la década de 1970, tema que abordaremos a continuación.

\section{- El estilo santamariano y su producción a lo LARGO DE MÁS DE 500 AÑos}

Una parte importante de las vasijas prehispánicas de Yocavil está constituida por aquellas denominadas santamarianas, de estilo inconfundible, pucos y grandes tinajas de entre 40 y $60 \mathrm{~cm}$ de altura. Estas últimas, urnas para el entierro de niños ${ }^{10}$, constituyen una referencia ineludible en cualquier consideración sobre el arte indígena precolombino del Noroeste Argentino. Ahora bien, este estilo que se ubicaría aproximadamente entre los siglos XI y XVII, tuvo a su vez una amplia presencia regional a lo largo de todo el valle Calchaquí. Dentro de esta extensión espacial y temporal se desarrollaron tanto variantes como cambios. En cuanto a las variantes regionales de este estilo, Caviglia (1985 Ms) distingue efectivamente cuatro expresiones o tradiciones: Calchaquí, Yocavil (Santa María), Cafayate (Valle Arriba) y Pampa Grande-Santa Bárbara. Prácticamente todas las vasijas santamarianas significativas para abordar el problema aquí planteado corresponden a la variante Yocavil.

El primer esfuerzo sistemático por estudiar los cambios en la producción de las urnas santamarianas de Yocavil en base a criterios morfológicos y decorativos, tuvo como protagonista a Ronald Weber quien en 1970 presentó una seriación de cinco fases a partir del estudio de la

\footnotetext{
${ }^{10}$ Estas grandes vasijas comúnmente utilizadas para el entierro de niños también han sido depositadas vacías como ofrendas en los entierros de adultos en cistas individuales o colectivas, $y$ a su vez fueron utilizadas en el ámbito doméstico para distintas funciones.
}

Colección Zavaleta depositada en el Museo de Historia Natural de Chicago y de las ilustraciones de la bibliografía publicada hasta el momento (Weber 1978). Más tarde Perrotta y Podestá retoman el trabajo de Weber apoyando y ampliando su seriación e incorporando a los pucos en el análisis, considerando además las asociaciones contextuales (Podestá y Perrotta 1973; Perrotta y Podestá 1974 Ms, 1978). Trabajan con las colecciones excavadas y documentadas por Weiser y Wolters en su recorrido por el valle de Yocavil desde Punta de Balasto hasta El Bañado de Quilmes (Colección Muñiz Barreto, depositada en el Museo de La Plata). Las autoras incorporan a las cinco fases de Weber, una nueva fase al comienzo de la secuencia. Como resultado del análisis de las urnas surge una secuencia de seis fases: O, I y II son tricolores (negro y rojo sobre baño blanco); III es tanto tricolor como bicolor y IV y V, exclusivamente bicolores (negro sobre baño blanco y, en menor medida, negro sobre baño rojo). Muy interesante es el estudio de 75 asociaciones urnas-pucos que otorgan un cuadro más completo a la seriación. Estos ordenamientos se basan en criterios morfológicos interrelacionados con las distintas características de la decoración pintada y modelada, desde los temas, el modo de representación y su distribución en el espacio plástico de la vasija. Según las autoras el cambio en la producción de las urnas santamarianas sería gradual, con lo cual las fases no constituirían entidades netamente delimitadas. En definitiva, la seriación no sería otra cosa que un modelo ideal que intenta dar cuenta de un cambio real. Por ejemplo, una de las tendencias morfológicas claves sería el progresivo incremento de la extensión del cuello junto con la disminución del cuerpo.

Si bien estudios posteriores basados en muestras cerámicas que aumentan la variabilidad manifiestan dificultades en aseverar la sucesión temporal estricta de cada tipo morfológico-decorativo y sugieren posibles contemporaneidades, lo cierto es que se sigue confirmando el orden cronológico de la secuencia y la temporalidad y asociaciones de determinadas fases. A esta altura está claro que tanto las urnas como los pucos de decoración tricolor son previos a los bicolores, distinción ya hecha por Márquez Miranda y Cigliano (1957). Las dos últimas fases propuestas por Perrotta y Podestá y Weber 
serían exclusivamente bicolores: ${ }^{11}$ las fases IV y V serían contemporáneas a la ocupación incaica, mientras que la Fase V se extendería hasta los primeros tiempos de la conquista española (siglos XVI-XVII). Es decir, la seriación permitió una aproximación al desarrollo cronológico del diseño de las urnas santamarianas variante Yocavil, que sucesivos hallazgos contextualizados permitieron evaluar favorablemente (ver p.e., Johansson 1996; Marchegiani 2004; Nastri 2006).

A esta seriación de urnas "típicas" deben agregarse las denominadas urnas Piriformes y Negro sobre Rojo. Con respecto a estas últimas, Weber y Perrotta y Podestá las ubican dentro de la Fase V (Perrotta y Podestá 1974 Ms: 28). Aunque teniendo en cuenta algunas piezas, como aquella ilustrada por Calderariy Williams (1991: 88, Lám. 1, Fig. D) con decoración en negro sobre rojo y con personajes humanos en las mejillas, podrían incluirse también en la Fase IV. Por su parte, las urnas piriformes, hasta el momento todas con decoración bicolor, se asociarían también a las últimas dos fases de la secuencia.

\section{* El estilo santamariano y el jaguar}

Cuando se refieren a la decoración de las urnas fases IV y V tanto Weber como Perrotta y Podestá mencionan un modo particular de representar al suri o ñandú propio de estas fases, que si bien ellos no asocian con lo felínico, otros autores comienzan a reconocer los rasgos felínicos representados en estos motivos (González 1974: 60-62; Kusch 1990: 19). Por lo tanto, en la vinculación del jaguar con el estilo santamariano, las representaciones de suris felinizados son aquellos motivos que surgen en primer lugar a la hora de caracterizar y discutir dicha vinculación.

El jaguar pintado que vemos en las urnas y pucos Santa María es en realidad una combinación de al menos dos

\footnotetext{
${ }^{11}$ Sin embargo, cabe mencionar que en los momentos más tardíos se registran algunos casos en donde se ha utilizado pintura roja en la decoración. Esto sucede, por ejemplo, en una urna claramente Fase $\mathrm{V}$ de Quilmes en donde el rojo aparece como color de fondo en la guarda lateral (pieza no 14 de la muestra; ver Figura 4).
}

especies, suri y jaguar, llama y jaguar o bien suri, llama y jaguar. Este motivo zoomorfo es exclusivo de las manifestaciones bicolores tardías. Weber sólo habla de distintos tipos de representaciones de suris, correspondiendo con la Variedad A aquellos que nosotros consideramos felinizados. Asíla define Weber: "la Variedad A posee un cuerpo amorfo y curvilíneo con patas y cuello delineados y anchos" (1978: 75. La traducción es nuestra). Según este autor, dicha variedad de suri sólo se registra en urnas de las fases IV y V.

Utilizando la misma ilustración de Weber, Perrotta y Podestá se refieren a esta variedad de suri (Variante C según las autoras) como "El camélido-suri", el mismo "aparece en ciertas urnas en que el suri está representado de tal manera que recuerda la figura de un camélido con mandíbula y dientes, patas gruesas con dedos, cola gruesa" (1974 Ms: 24. Subrayado es nuestro). Esta variedad de suri junto a la Variante D: "cuerpo curvilíneo, cuello grueso formado por dos líneas finas. Las patas son gruesas y rectangulares; la cola, gruesa" (1974 Ms: 24), aparecen según Perrotta y Podestá en las últimas fases de la secuencia. Ni Weber ni Perrotta y Podestá mencionan como característica distintiva de algún tipo de representación de suri, manchas en el cuerpo, aun cuando las están ilustrando. Estas son para nosotros las manchas del jaguar (Figura 1).

Autores anteriores también abordan este motivo, aunque sin identificar su carácter felínico. Así, por ejemplo, Ambrosetti (1896-99: XXIV "El símbolo del suri") describe la evolución del símbolo del suri en la cerámica santamariana. Para esto parte de las representaciones que aquí denominamos felinizadas o más precisamente jaguarizadas, a las que luego seguirían las imágenes más realistas de suris (1896-99: 177). Las primeras imágenes estarían representando para este autor a Piguerao, el pájaro de las tormentas, compañero de Catequil, el rayo. Ambrosetti comienza con una extensa descripción del animal protagonista pintado en el interior de una escudilla (pieza $n^{\circ} 15$ en la muestra; ver Figura 5 más adelante) y continúa ejemplificando la representación de Piguerao con otros motivos zoomorfos del mismo estilo. Destaca de estas imágenes el carácter de ferocidad: cuerpos principalmente con círculos, puntos y también 


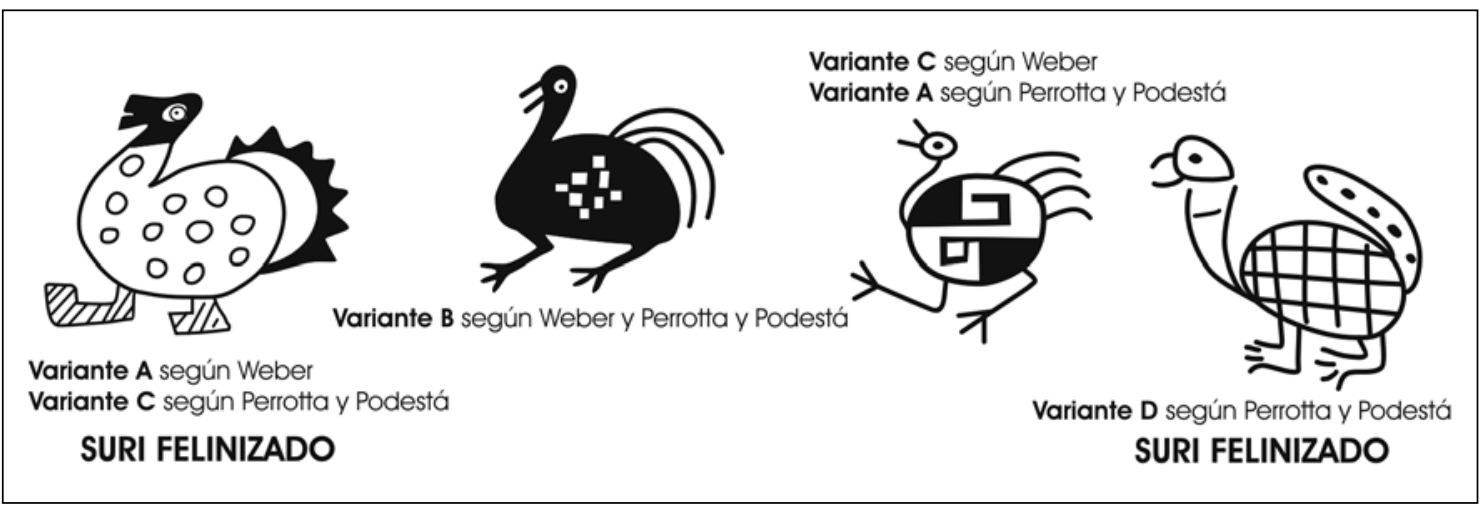

Figura 1. Variantes de representaciones de suris según Weber (1978) y Perrotta y Podestá (1974 Ms). La primera y última serían las variantes actualmente definidas como felinizadas.

reticulados y grecas; cuellos anchos cruzados por líneas transversales o rellenos con puntos; algunos con cuernos; colas anchas, erguidas, a veces enroscadas y con puntos o círculos en su interior; picos abiertos; patas anchas también con líneas transversales o puntos, o terminadas con círculos con rayas o puntos en su alrededor (hasta hay un caso de "suri" con cuatro patas). Ambrosetti sostiene una interpretación curiosa sobre los círculos, puntos o círculos con puntos centrales, pintados en el interior del cuerpo y de la cola de estos animales: serían los huevos del ave mítica (1896-99: 173). Aquí, como ya mencionamos, interpretamos dichos rasgos como las manchas del pelaje del jaguar.

En otro trabajo, Ambrosetti (1902: 141-42) ilustra las representaciones de suris santamarianos (entre motivos ornitomorfos de otros estilos y también del arte rupestre) agrupadas en dos series "con caracteres propios, que las hacen inconfundibles". La primera serie está integrada por: "Animales con cuernos, dientes y cola, bien distinta, en espiral o arqueada hacia arriba, o con cualquiera de estos elementos, sin indicación de plumas". Estos animales son los que aquí consideramos suris felinizados. Por su parte, la segunda serie está formada por: "Animales sin cuernos, dientes ni cola, con plumas o sin ellas y aspecto de avestruz o suri". Vemos entonces que la distinción formal de dos tipos de representaciones de suris, aquellas totalmente asimilables con el suri propiamente dicho, y por otro lado las que presentan atributos extraños a dicha especie, es por cierto ya muy antigua, aun cuando no se asocie esta diferencia con el carácter felínico de las segundas (y menos aún con argumentos cronológicos).

Un rasgo adicional que nos permitiría identificar el jaguar en el suri es la cantidad de dedos. González (2004: 27) presenta el mismo argumento para diferenciar las representaciones de llamas con dos dedos de aquellas de felinos con sus característicos "cuatro dedos". En los "suris" santamarianos de Yocavil podemos distinguir efectivamente algunos con tres dedos y otros con cuatro (existen casos con un número mayor de dedos). Aquellos que tienen cuatro dedos se corresponden sólo con algunas de las imágenes zoomorfas pintadas en las urnas Fase IV (aunque a veces el mismo animal tiene patas de tres y cuatro dedos). También pudimos observar un caso de "suri" con cuatro patas (el mismo que notara Ambrosetti; pieza ${ }^{\circ} 2$ en la muestra; ver Figura 3 más adelante). Otro rasgo que aparece en algunos de los animales de la Fase IV son orejas que no corresponderían con un suri, pero sí con un jaguar o un camélido.

Hasta aquí algunas referencias vinculadas con los suris felinizados. Sin embargo, para profundizar este estudio fue necesario iniciar un examen amplio de vasijas santamarianas ilustradas en la bibliografía y depositadas en distintos museos, para definir de manera explícita y sistemática la presencia del felino en la iconografía del Período Tardío de Yocavil. 


\section{* ANÁlisis DE LA MUESTRA}

Como resultado de nuestra búsqueda, se conformó una muestra de 54 vasijas o fragmentos de vasijas de estilo santamariano, básicamente en su variante Yocavil, en donde se aprecian motivos felínicos. Las mismas fueron recopiladas de la bibliografía ${ }^{12}$, de registros realizados en distintos museos ${ }^{13} y$ del material de excavación producto de las investigaciones del Proyecto Arqueológico Yocavil. ${ }^{14}$ Efectivamente, las representaciones de jaguares que conforman la muestra no se restringen simplemente a los suris felinizados pintados en urnas, sino que también se observaron representaciones pintadas en pucos, serpientes felinizadas pintadas en urnas y jaguares modelados en pucos y urnas piriformes. En todos los casos se trata de vasijas bicolores con decoración en pintura negra sobre baño blanco ${ }^{15}$ exceptuando algunas vasijas con decoración en negro sobre baño rojo.

El tamaño acotado de la muestra se debe a que las piezas con motivos felínicos corresponden a un porcentaje muy bajo respecto del total de vasijas santamarianas. Por un lado, esto podría explicarse por la mayor abundancia de urnas tricolores en comparación con las bicolores y, por otro lado, a que aquellas vasijas con motivos felínicos constituirían un grupo poco numeroso dentro de la variante bicolor.

La muestra de vasijas analizadas se dividió en dos conjuntos teniendo en cuenta la manera de materializar plásticamente el motivo del jaguar: "jaguar pintado"

\footnotetext{
12 Liberaniy Hernández 1950 [1877]; Ambrosetti 1896-99, 1902, 1907; Bruch 1911; Quiroga 1994 [1929]; Wagner y Wagner 1934; Márquez Miranda 1936, 1946; Márquez Miranda y Cigliano 1957; Serrano 1966; Ibarra Grasso 1971; González 1974, 1980; Kusch 1990; Tarragó 1995; Tarragó et al.. 1997; Stenborg y Muñoz 1999; Tancredi et al.. 2004 Ms; Velandia 2005; Nastri 2006.

13 Museo Etnográfico "Juan B. Ambrosetti" de Buenos Aires; Museos "Eric Boman" y "Adán Quiroga" de la provincia de Catamarca; Museo de las Ruinas de Quilmes, Tucumán; Museo de Cachi, Salta.

${ }^{14}$ Museo Etnográfico "Juan B.Ambrosetti" (Facultad de Filosofía y Letras, Universidad de Buenos Aires), dirigido por la Dra. Myriam Tarragó.

15 Cabe mencionar que una urna Fase $\mathrm{V}$ procedente de Quilmes, referida en la Nota 3, posee pintura roja. Por su parte, una escudilla con jaguar modelado procedente de la región de Cachi (pieza n ${ }^{\circ} 52$ ) presenta también pintura roja al interior de grecas escalonadas.
}

(dos dimensiones) y "jaguar modelado" (tres dimensiones). Estos dos conjuntos están conformados a su vez por morfologías cerámicas distintas, así dentro del grupo "jaguar pintado" encontramos las típicas vasijas o urnas funerarias y pucos (habría una excepción: una urna piriforme que combina jaguares pintados y modelados); mientras que las formas registradas dentro del conjunto "jaguar modelado" son las vasijas piriformes, vasijas zoomorfas, pucos globulares con apéndices, y grandes apéndices modelados de vasijas de formas no observables.

Del total de la muestra, 31 vasijas presentan motivos felínicos pintados, mientras que 23 presentan jaguares modelados. Las piezas proceden de todo el valle de Yocavil:Anjuana, Quilmes, El Bañado, Amaicha, Rincón Chico, Lorohuasi, Las Mojarras, Fuerte Quemado, San José, quebrada de Shiquimil, Loma Rica de Shiquimil, Punta de Balasto, Famabalasto, Santa María y región de Santa María. También forman parte de la muestra vasijas procedentes de localidades ubicadas fuera del valle de Yocavil: Pueblo del Molino de Corral Quemado y Andalgalá (Catamarca); Casa Morada de La Paya, Tero, y región de Cachi (Salta). Una pieza tiene procedencia de Catamarca, otra de Argentina y finalmente una con procedencia desconocida (Figura 2, Tablas 1 y 2).Vemos, como resultado de esta búsqueda, que las piezas no se restringen geográficamente a una localidad o sector de Yocavil y que inclusive encontramos vasijas fuera de esta región. En esta enumeración de procedencias se mantuvieron las referencias recopiladas de las distintas fuentes (bibliografía y catálogos de museos), aun considerando los diferentes niveles de precisión de las mismas y los solapamientos resultantes. En pocos casos contamos con el nivel de sitio y en menos aún con la posibilidad de conocer el contexto de hallazgo. Las referencias mayoritarias están dadas a nivel de localidad actual, por ejemplo, Santa María, San José, Amaicha. Por otra parte, muchas de las vasijas que conforman la muestra sólo pudieron incorporarse en base a dibujos o fotografías (sobre todo aquellas publicadas por los pioneros) y por este motivo no fue posible la observación y el registro de la pieza completa, inconveniente no menor a la hora de cualquier análisis iconográfico. Sin embargo, quizás sea esta la única manera de acercarnos a algunas vasijas. 


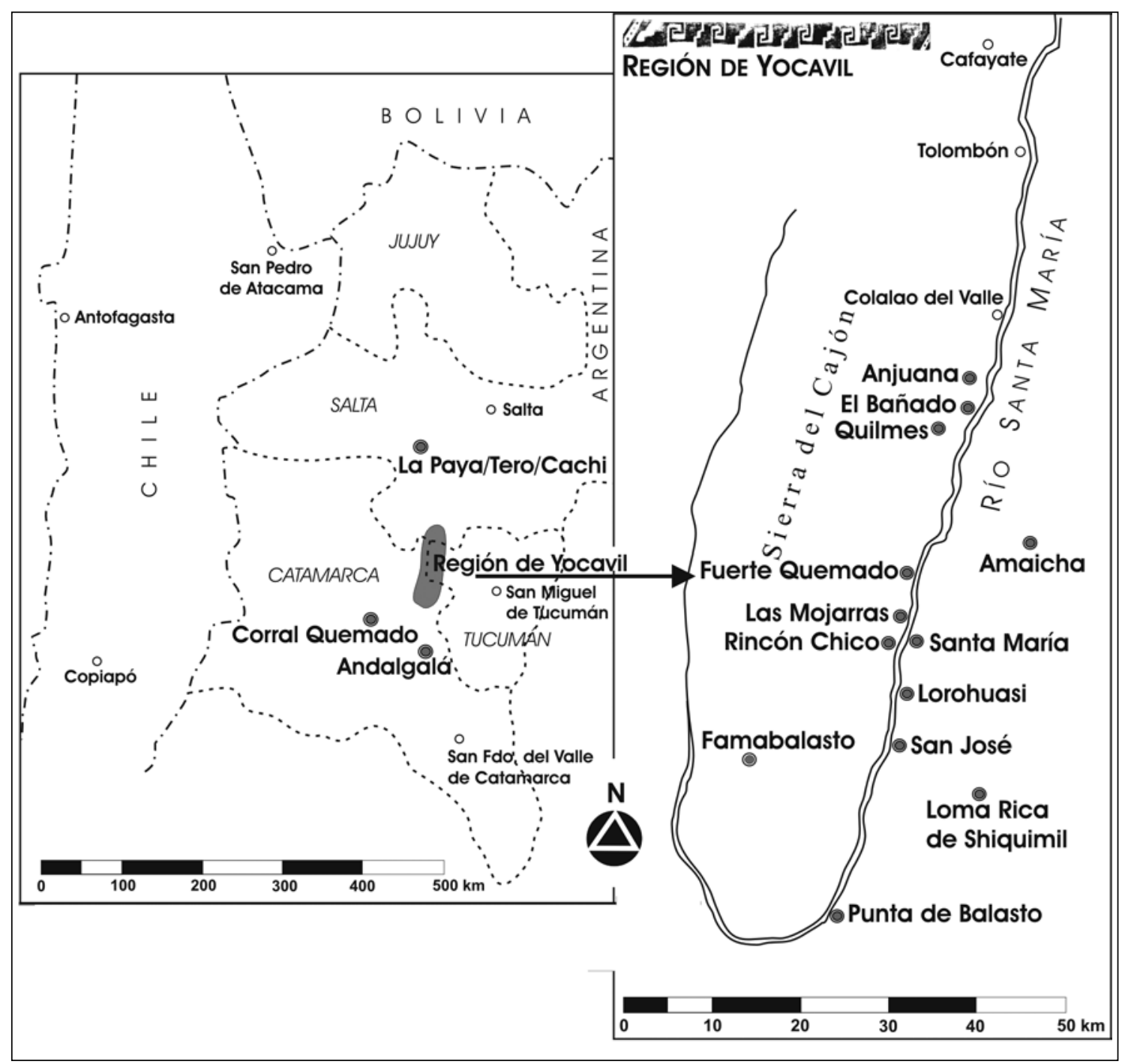

Figura 2. Procedencias de las vasijas que conforman la muestra.

Con todo, este trabajo elaborará una discusión a partir de cierto marco empírico que no se considera agotado ni cerrado. Futuras incorporaciones sustentarán o no dicha discusión.

Jaguar pintado. La totalidad de las urnas santamarianas con motivos felínicos pintados que conforman la muestra corresponden a las fases IV y V de la seriación ya mencionada. Con respecto a las urnas Fase IV, de un total de 20 vasijas, tres proceden de San José, cuatro de Fuerte Quemado, tres de Punta de Balasto, una de Quilmes, una de Lorohuasi, una de quebrada de Shiquimil, una de Loma Rica de Shiquimil, una de Amaicha, dos de
Santa María, dos de la región de Santa María y una de procedencia desconocida (Figura 3).

Vemos que el jaguar pintado en las urnas correspondientes a la Fase IV ocupa siempre un lugar importante en el espacio plástico de las vasijas, en el exterior y en la parte del cuerpo, salvo en un caso en donde se ubican en el cuello (pieza n 22; Tarragó et al.. 1997: 229, Fig. 5.b; Nastri 2006: pieza ${ }^{\circ} 73$, Lám. 27). La base de estos motivos es sin duda el suri, ave ampliamente representada en las urnas de las fases anteriores. La novedad en la Fase IV es, como vimos, que a la representación de estos animales se le incorporan rasgos felínicos: manchas de jaguar, 


\begin{tabular}{|c|c|c|c|}
\hline $\mathrm{N}^{\mathrm{o}}$ & Procedencia & Forma & Referencias \\
\hline 1 & Santa María (Catamarca) & Urna Fase IV & $\begin{array}{l}\text { Ambrosetti 1896/99: XXIV “El símbolo del suri”: 176, Figs. } 173 \text { y 173a; Nastri 2006: } \\
\text { pieza no 32, Lám. 21. MEJBA 73-34 }\end{array}$ \\
\hline 2 & San José (Catamarca) & Urna Fase IV & Ambrosetti 1896/99:XXIV “El símbolo del suri”: 176, Fig. 174. MEJBA 73-52 IG \\
\hline 3 & Amaicha (Tucumán) & $\begin{array}{l}\text { Urna Fase IV } \\
\text { (diseño aislado) }\end{array}$ & Ambrosetti 1896/99:XXIV “El símbolo del suri”: 173, Fig. 168 \\
\hline 4 & San José (Catamarca) & Urna Fase IV & $\begin{array}{l}\text { Ambrosetti 1896/99: XXIV “El símbolo del suri”: 175, Fig. 171; Nastri 2006: pieza } \\
\text { n 369, Lám. 49. }\end{array}$ \\
\hline 5 & Lorohuasi (Catamarca) & Urna Fase IV & Márquez Miranda 1946: 149, Fig. 55.a. Velandia 2005: 179, Fig. 51. MLP nº 5968 \\
\hline 6 & $\begin{array}{l}\text { Loma Rica de Shiquimil } \\
\text { (Catamarca) }\end{array}$ & Urna Fase IV & $\begin{array}{l}\text { Liberani y Hernández } 1950 \text { [1877]: n } 4 \text {; Ambrosetti 1896/99:XXIV “El símbolo del } \\
\text { suri": 175, Fig. 172; Nastri 2006: pieza no } 371 \text {, Lám. } 49 .\end{array}$ \\
\hline 7 & Desconocida & Urna Fase IV & Ibarra Grasso 1971:368; Nastri 2006: pieza no 82, Lám. 28. MEJBA 28048 \\
\hline 8 & Quilmes (Tucumán) & Urna Fase V & Nastri 2006: pieza n 635, Lám. 82. MAJBA \\
\hline 9 & Quilmes (Tucumán) & Urna Fase IV & MAJBA \\
\hline 10 & Región de Santa María & Urna Fase IV & MAPEB n 226 \\
\hline 11 & Punta de Balasto (Catamarca) & Urna Fase IV & $\begin{array}{l}\text { Márquez Miranda y Cigliano 1957: Lám. II.a; González 1980: 331; Kusch 1990: 19, } \\
\text { Fig. 5. Velandia 2005: 183, Lám. 19. MLP nº } 4415\end{array}$ \\
\hline 12 & El Bañado (Tucumán) & Urna Fase V & González 1980:331. MLP nº 4536 \\
\hline 13 & Región de Santa María & Urna Fase IV & MAAQ \\
\hline 14 & Quilmes (Tucumán) & Urna Fase V & Nastri 2006: pieza no 884, Lám. 91. MAJBA \\
\hline 15 & $\begin{array}{l}\text { Orillas Río Aguasana, Andalgalá } \\
\text { (Catamarca) }\end{array}$ & Puco con cuello & $\begin{array}{l}\text { Ambrosetti 1896/99: XXIV "El símbolo del suri": 172, Fig. 167; Quiroga } \\
1994 \text { [1929]: 71, Fig. 49; Tancredi et al. } 2004 \text { Ms: pieza nº 63. MEJBA } 30010\end{array}$ \\
\hline 16 & $\begin{array}{l}\text { Rincón Chico -Sitio } \\
\text { 21-(Catamarca) }\end{array}$ & Puco & Proyecto Arqueológico Yocavil (MAPEB). RCh 21, Cista 15 \\
\hline 17 & Las Mojarras (Catamarca) & $\begin{array}{l}\text { Puco con impronta de } \\
\text { cestería }\end{array}$ & Tarragó 1995: Fig. 8. MAPEB n 57 CB \\
\hline 18 & Santa María (Catamarca) & Puco (diseño aislado) & $\begin{array}{l}\text { Ambrosetti 1896/99: XXIV “El símbolo del suri”: 174, Fig. 170; Quiroga } 1994 \\
\text { [1929]:46, Fig. 46. }\end{array}$ \\
\hline 19 & San José (Catamarca) & $\begin{array}{c}\text { Urna Fase IV } \\
\text { (diseño aislado) }\end{array}$ & Quiroga 1994 [1929]: 71, Fig. 51. \\
\hline 20 & Fuerte Quemado (Catamarca) & Urna Fase IV & Nastri 2006: pieza nº 22, Lám. 18. MEJBA Z-8473 (067) \\
\hline 21 & Fuerte Quemado (Catamarca) & Urna Fase IV & Nastri 2006: pieza nº 554, Lám. 78. EM VC 593503641 \\
\hline 22 & Fuerte Quemado (Catamarca) & Urna Fase IV & Tarragó et al. 1997: 229, Fig. 5.b; Nastri 2006: pieza nº.73, Lám. 27. MEJBA 44-1885 \\
\hline 23 & Fuerte Quemado (Catamarca) & Urna Fase V & Bruch 1911: 96 , Figs. 96 y 96 bis. MLP n ${ }^{\circ} 41$ \\
\hline 24 & Fuerte Quemado (Catamarca) & Urna Fase IV & Wagner y Wagner 1934: 110, Fig. 121. MEJBA Z-8473/067 \\
\hline 25 & San José (Catamarca) & Puco (diseño aislado) & Ambrosetti 1902: 142, Fig. Serie A.7. \\
\hline 26 & Santa María (Catamarca) & $\begin{array}{c}\text { Urna Fase IV } \\
\text { (diseño aislado) }\end{array}$ & Ambrosetti 1902: 142, Fig. Serie A.10. \\
\hline 27 & Santa María (Catamarca) & Puco (diseño aislado) & Ambrosetti 1902: 142, Fig. Serie A.1. \\
\hline 28 & Punta de Balasto (Catamarca) & Urna Fase IV & Márquez Miranda 1936:318 y 320, Fig. 11 y 12. Velandia 2005: 175, Lám. 17. MLP nº 4414 \\
\hline 29 & Punta de Balasto (Catamarca) & Urna Fase IV & Márquez Miranda 1936:321, Fig. 13. Velandia 2005: 183, Lám. 19. MLP nº 4426 \\
\hline 30 & $\begin{array}{l}\text { Quebrada de Shiquimil } \\
\text { (Catamarca) }\end{array}$ & Urna Fase IV & Márquez Miranda 1946: 155, Fig. 59.a. MLP nº 5701 \\
\hline 31 & Las Mojarras (Catamarca) & Puco & Márquez Miranda 1946: Lám. X.f. MLP nº 154 \\
\hline
\end{tabular}

Tabla 1. Listado de las vasijas santamarianas con motivos felínicos pintados que integran la muestra. ${ }^{16}$

\footnotetext{
${ }^{16}$ Abreviaturas de Museos:

MEJBA: Museo Etnográfico “Juan B. Ambrosetti” (Buenos Aires, Argentina).

MLP: Museo de La Plata (La Plata, Buenos Aires).

MAPEB: Museo Arqueológico Provincial “Eric Boman” (Santa María, Catamarca).

MAJBA: Museo Arqueológico “Juan Bautista Ambrosetti” (Quilmes, Tucumán).

MAC: Museo Arqueológico de Cachi (Cachi, Salta).

MAAQ: Museo Arqueológico "Adán Quiroga" (San Fernando del valle de Catamarca, Catamarca).

EM: Ethnologisches Museum (Berlín).

EMG: Etnografiska Museet I Göteborg (Gotemburgo).
} 


\begin{tabular}{|c|c|c|c|}
\hline $\mathrm{N}^{\circ}$ & Procedencia & Forma & Referencias \\
\hline 32 & Palo Seco, San José (Catamarca) & Apéndice zoomorfo & MAPEB \\
\hline 33 & Región de Santa María & Apéndice zoomorfo & $\begin{array}{c}\text { Ambrosetti 1896/99: VIII “Representaciones de tigres": } 533, \\
\text { Fig. } 34\end{array}$ \\
\hline 34 & Fuerte Quemado (Catamarca) & Apéndice zoomorfo & $\begin{array}{c}\text { Ambrosetti 1896/99: VIII “Representaciones de tigres": 534, } \\
\text { Fig. } 35 \text { y35a. MEJBA Z-34-D, 47/1180 }\end{array}$ \\
\hline 35 & Fuerte Quemado (Catamarca) & Apéndice zoomorfo & $\begin{array}{c}\text { Ambrosetti 1896/99: VIII “Representaciones de tigres": } 535, \\
\text { Fig. } 36 \text { y } 36 \text { 6a. MEJBA } 25368\end{array}$ \\
\hline 36 & Fuerte Quemado (Catamarca) & Urna piriforme & Wagner y Wagner 1934: 178; Serrano 1966: Lám. VI.1. \\
\hline 37 & Santa María (Catamarca) & Urna piriforme & $\begin{array}{c}\text { Ambrosetti 1896/99: XXIII “Amuleto ofidio fálico para la } \\
\text { lluvia": 170, Fig. 163; Nastri 2006: pieza n 70, Lám. 27. MEJBA } \\
36980\end{array}$ \\
\hline 38 & $\begin{array}{c}\text { Piedra Blanca, San José } \\
\text { (Catamarca) }\end{array}$ & Urna piriforme & Stenborg y Muñoz 1999: 147. EMG n 1930.39.1 \\
\hline 39 & Famabalasto (Catamarca) & Variedad Urna piriforme & $\begin{array}{l}\text { Márquez Miranda 1946: 171, Fig. 69.b; Nastri 2006: pieza } \\
\text { nº 639, Lám. 83. MLP N }{ }^{\circ} \text { MB } 5266\end{array}$ \\
\hline 40 & Anjuana (Tucumán) & Apéndice zoomorfo & Liberani y Hernández 1950 [1877]: Lám. 22 \\
\hline 41 & Quilmes (Tucumán) & Variedad Urna piriforme & MAJBA \\
\hline 42 & Amaicha (Tucumán) & Puco con apéndice zoomorfo & MEJBA 44-2080 (101) \\
\hline 43 & $\begin{array}{l}\text { Pueblo del Molino, Corral } \\
\text { Quemado (Catamarca) }\end{array}$ & Urna piriforme & $\begin{array}{l}\text { González 1974: 60-61, Fig. 15; Nastri 2006: pieza no 638, Lám. } \\
\text { 83. Velandia 2005: 188, Figs. } 57 \text { y 58. MLP González } 116\end{array}$ \\
\hline 44 & Santa María (Catamarca) & Apéndice zoomorfo & Quiroga 1994 [1929]: 68, Fig. 45. \\
\hline 45 & San José (Catamarca) & Apéndice zoomorfo & Quiroga 1994 [1929]: 172, Fig. 156. \\
\hline 46 & Tero, Cachi (Salta) & Puco con apéndice zoomorfo & $\mathrm{MAC} \mathrm{n}^{\circ} 2402$ \\
\hline 47 & Catamarca & Puco con apéndice zoomorfo & Wagner y Wagner 1934: 57, Fig. 60. \\
\hline 48 & Quilmes (Tucumán) & Puco con apéndice zoomorfo & MEJBA 25079 \\
\hline 49 & Argentina & Puco con apéndice zoomorfo & MEJBA 36809 \\
\hline 50 & Amaicha (Tucumán) & Puco con apéndice zoomorfo & MEJBA 37022 \\
\hline 51 & $\begin{array}{l}\text { Rincón Chico, Sitio } 15 \\
\text { (Catamarca) }\end{array}$ & Apéndice zoomorfo & $\begin{array}{l}\text { Proyecto Arqueológico Yocavil (MEJBA). RCh 15, E3, M12, 225.1, } \\
\qquad 10610\end{array}$ \\
\hline 52 & Región de Cachi (Salta) & Puco con apéndice zoomorfo & $\mathrm{MAC} \mathrm{n}^{\circ} 809$ \\
\hline 53 & Fuerte Quemado (Catamarca) & Apéndice zoomorfo & MEJBA Z-7687-B \\
\hline 54 & La Paya, Casa Morada (Salta) & Vasija zoomorfa & Ambrosetti 1907: 52, Fig. 28. MEJBA 4102-11, 1904/48 \\
\hline
\end{tabular}

Tabla 2. Listado de las vasijas santamarianas con motivos felínicos modelados que integran la muestra. ${ }^{16}$

fauces, garras, orejas y cola (enroscada o doblada hacia arriba). Aunque cabe mencionar que la representación del suri propiamente dicho no se abandona.

En todos los casos considerados, salvo en dos vasijas (piezas nºs 4 y 5 , respectivamente, Ambrosetti 1896-1899: XXIV “El símbolo del suri”: 175, Fig. 171 y Márquez Miranda 1946: 149, Fig. 55.a), los motivos de suris felinizados (jaguarizados) se presentan de a pares. Estos animales siempre están acompañados por las imágenes humanas comúnmente denominadas "guerreros", ubicadas en las mejillas de las urnas, motivos también novedosos y característicos de esta fase. Sólo encontramos dos casos (piezas $n^{\circ}$ s 13 y 30 ; para esta última, ver Márquez Miranda 1946: 155, Fig. 59.a) en donde en lugar de personajes humanos la urna presenta serpientes y cinco casos en donde no conocemos la vasija completa. Al mismo tiempo, hay una vasija interesante en la cual podemos apreciar una equivalencia entre el suri felinizado y los personajes humanos referidos. Se trata de la vasija Fase IV ( pieza n $^{\circ} 22$ ) que en una de sus caras presenta dos suris felinizados en las mejillas, mientras que en la otra cara también en las mejillas aparecen esta vez dos personajes humanos (Nastri 2006: 140). Estos personajes o "guerreros" también se encuentran en algunos aribaloides incaicos locales y por este motivo constituyeron un elemento clave a la hora de construir la seriación de urnas santamarianas (Podestá y Perrotta 1973: 10; Weber 1978: 81-82, Fig. 15). Cabe mencionar que otro motivo presente tanto en aribaloides como en 

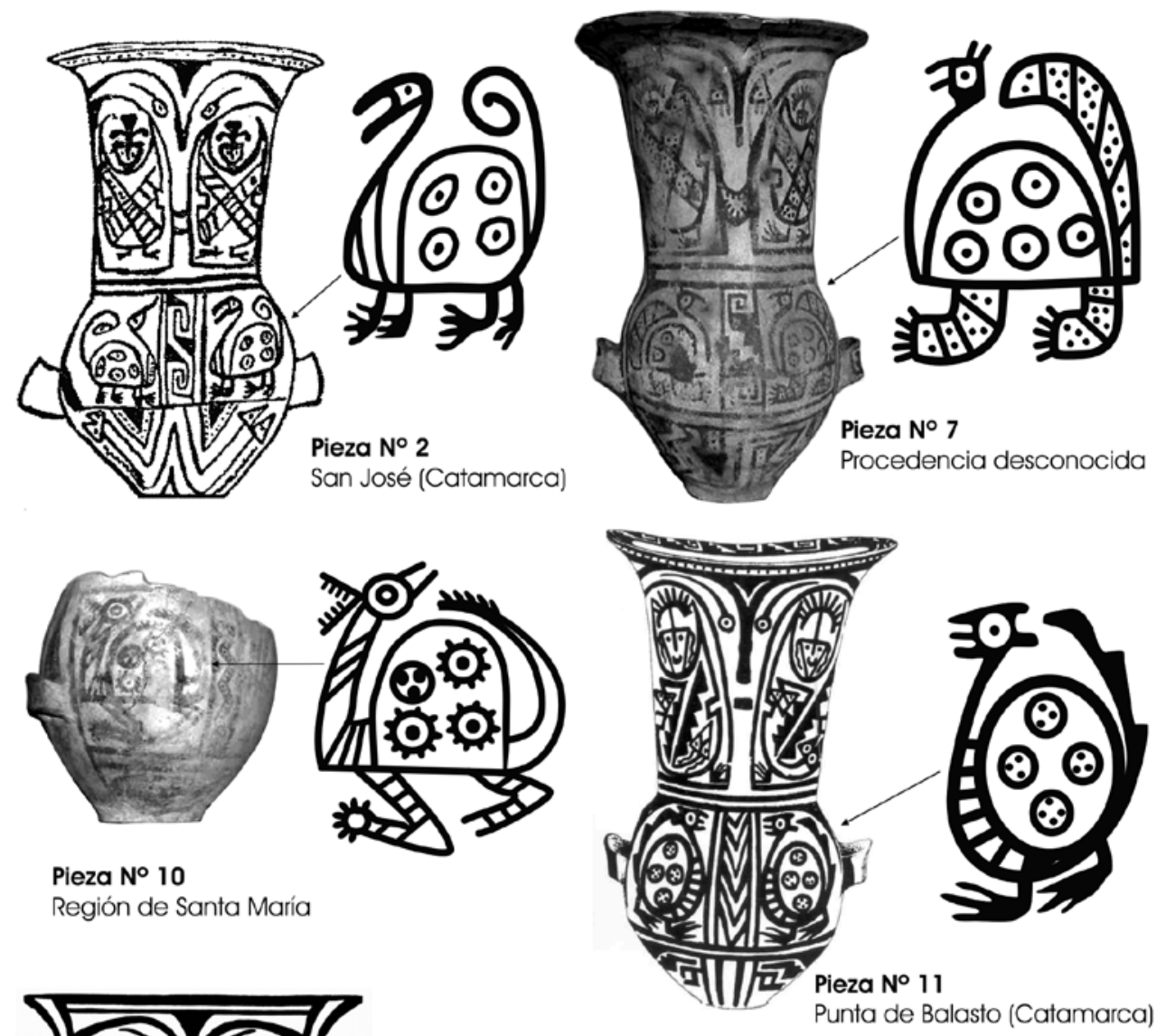

Región de Santa María

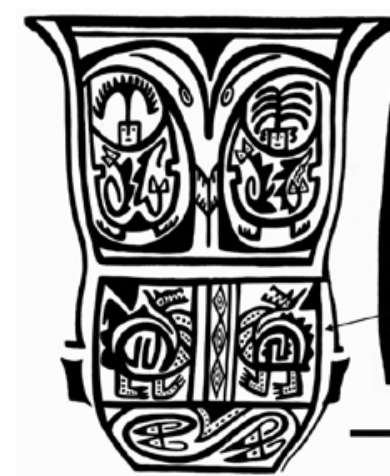

Pieza $\mathbf{N}^{\circ} 28$

Punta de Balasto (Catamarca)

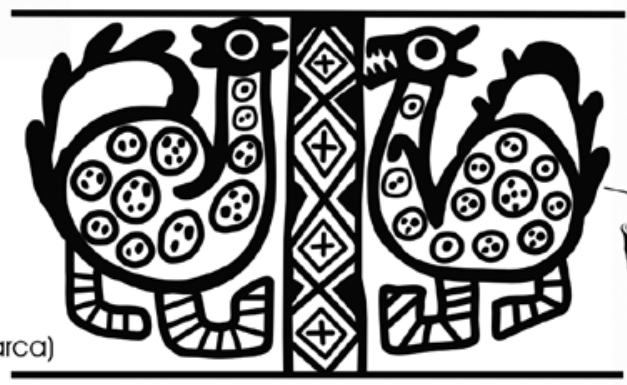

Pieza No 24

Fuerte Quemado

(Catamarca)

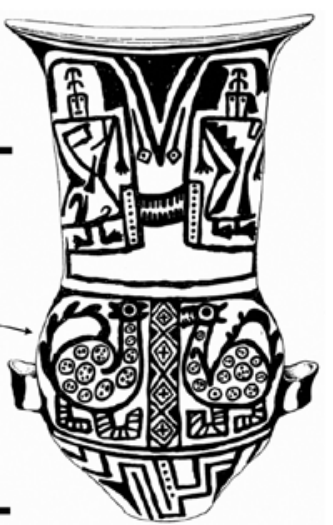

Figura 3. Representaciones felínicas pintadas. Algunas urnas santamarianas Fase IV de la muestra. 
urnas santamarianas de las fases IV y V es el ave bicéfala con cuerpos triangulares. ${ }^{17}$ Este mismo motivo también se observa en urnas de la variante Cafayate o Valle Arriba y en una de ellas se asocia con representaciones felínicas (Serrano 1966: Lám. IV.3).

En un trabajo reciente se analiza una muestra comprendida por 773 vasijas pertenecientes al Período Tardío, de las cuales 717 corresponden a urnas santamarianas de la variedad Yocavil (Nastri 2006). En dicho trabajo, que tiene como objetivo adentrarse en el simbolismo de la iconografía santamariana así como su variación espacial y temporal, se ratifica que los motivos felínicos sólo se encuentran en las fases IV y V de Weber y de Perrotta y Podestá. Además, se pone énfasis en la asociación de los motivos felínicos con otros que denotan situaciones de violencia como son los denominados "guerreros" de la Fase IV, algunos de los cuales portan cabezas cercenadas en una de sus manos.

Con respecto a las cuatro urnas Fase $\mathrm{V}$ con representaciones de motivos felínicos, dos provienen de Quilmes, una de El Bañado y finalmente otra de Fuerte Quemado (Figura 4). En general, el motivo felinizado que se pintó,

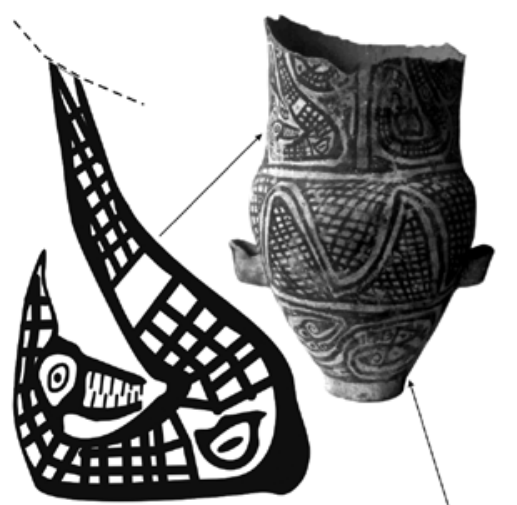

Pieza No 8

Quilmes (Tucumán)

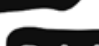

(1)

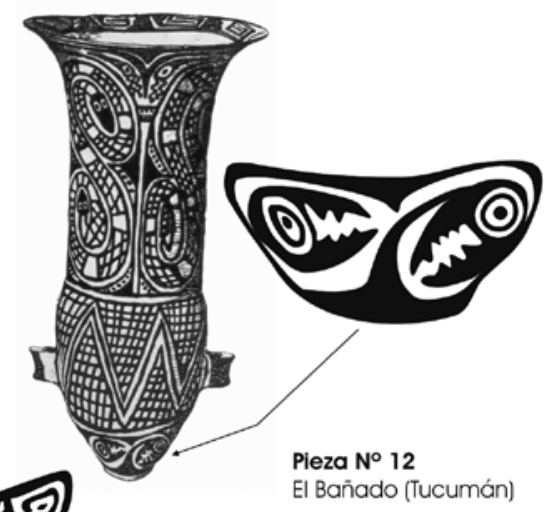

Pieza No 12

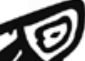
Diseño en la base
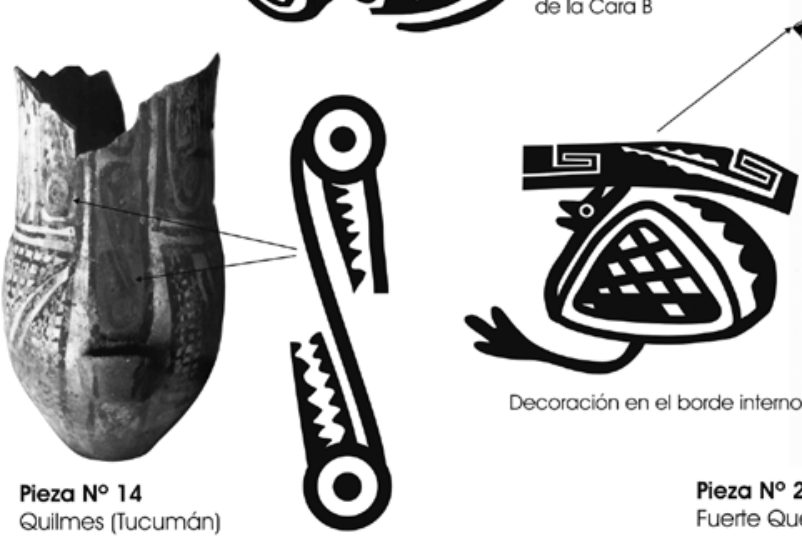

Decoración en el borde interno

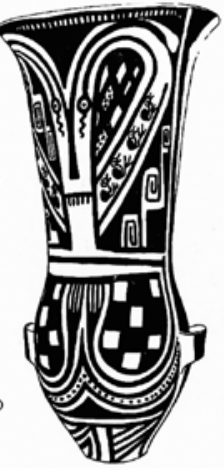

Pieza No 23

Fuerte Quemado (Catamarca)

Figura 4. Representaciones felínicas pintadas. Algunas urnas santamarianas Fase V de la muestra.

\footnotetext{
${ }_{17}$ Para un ejemplo de aribaloide incaico ver Weber (1978: 82, Fig. 15) y para las vasijas santamarianas ver Márquez Miranda (1946: 158, Fig. 62.a).
} 
esta vez en los cuellos y bases de las urnas, son las fauces con un único ojo concéntrico (motivos que nos recuerdan a algunas fauces felínicas tanto de Aguada como de otras antiguas representaciones andinas) como cabezas de cuerpos serpentiformes. Si bien el suri felinizado no es propio de las urnas de esta fase, en la muestra podemos observar una de estas vasijas con un motivo de suri pintado en el interior del borde que presenta algunos rasgos similares a aquellos de las urnas Fase IV: con orejas y cola larga doblada hacia arriba (pieza n²3, Figura 4).

Los pucos con representaciones felínicas pintadas de la muestra son siete y proceden de Rincón Chico (Sitio 21), San José, Andalgalá, dos de Las Mojarras y, por último, dos de Santa María. En esta forma siempre los animales están pintados en el interior. Al igual que en las urnas Fase IV se pintaron suris feminizados, pero en esta oportunidad algunas de las representaciones también parecerían poseer rasgos de camélidos (Figura 5).
Todos los pucos, los cuales presentan decoración interna de motivos zoomorfos y uno de ellos de borde con "cuello", corresponderían a la última fase de la seriación de pucos propuesta por Perrotta y Podestá, coincidiendo con los momentos más tardíos. La guarda interna y externa de dos de ellos (piezas nos 15 y 17; ver Figura 5) se vincula con el tipo de guardas internas pintadas en el borde de las urnas más tardías.

Jaguar modelado. Pasando a las urnas con motivos felínicos modelados, tenemos cuatro grandes vasijas denominadas piriformes y dos piezas más que podrían ser variantes de esta forma, una de ellas de tamaño pequeño. Proceden de Fuerte Quemado, Piedra Blanca (San José), Famabalasto, Quilmes, Pueblo del Molino de Corral Quemado y Santa María. Las vasijas piriformes presentan dos cabezas de jaguares o de murciélagos felinizados en los laterales del cuerpo por encima de las asas (Figura 6). La pieza de Corral Quemado además de las cabezas de jaguar

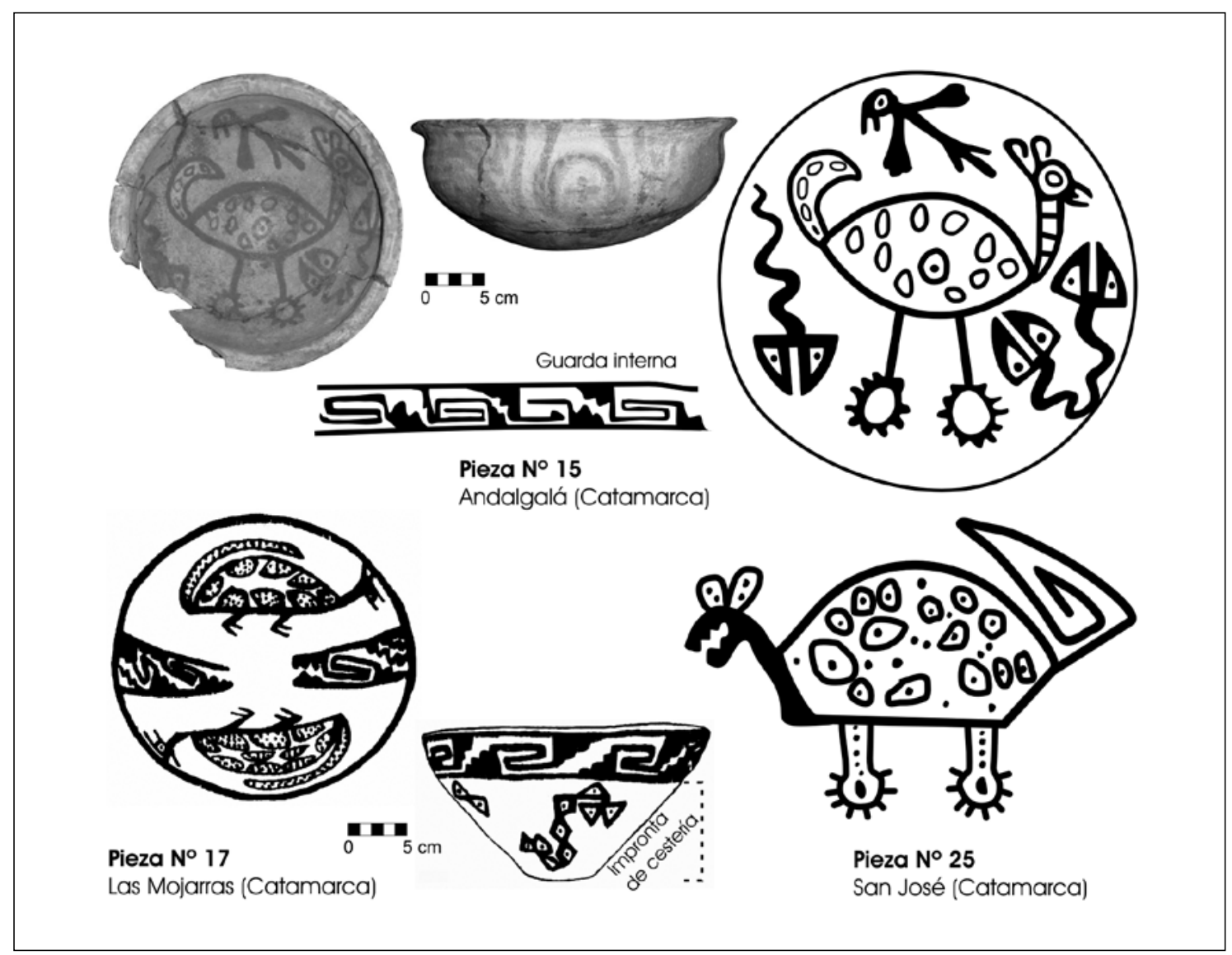

Figura 5. Representaciones felínicas pintadas. Algunos pucos santamarianos de la muestra. 

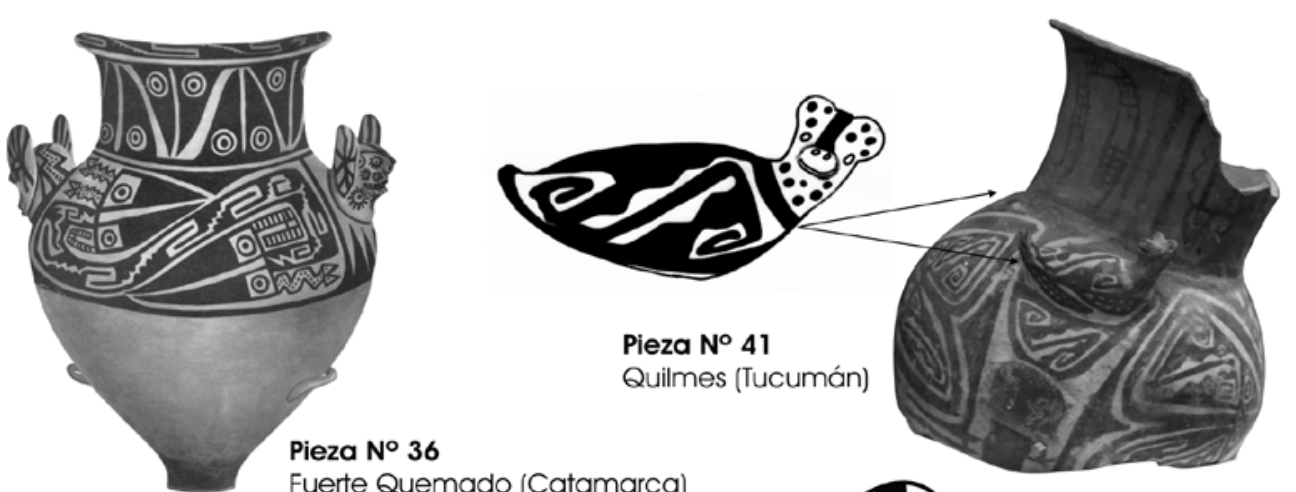

Fuerte Quemado (Catamarca)

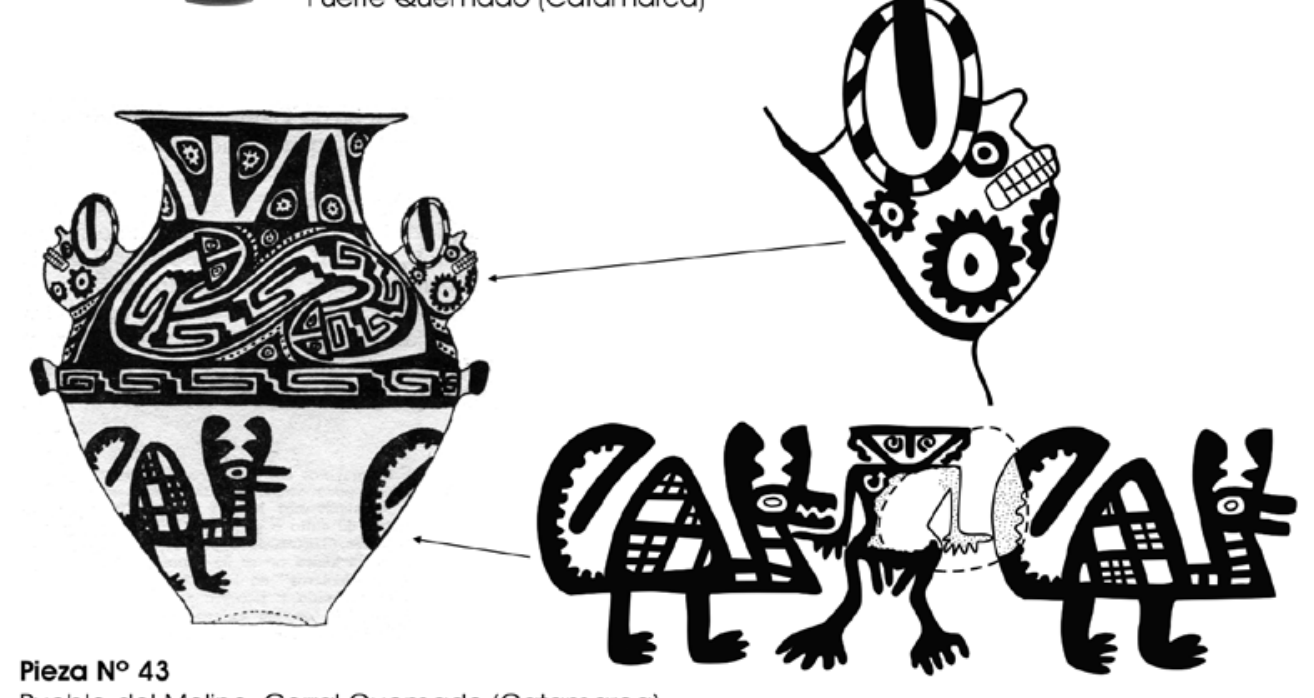

Pueblo del Molino, Corral Quemado (Catamarca)

Figura 6. Representaciones felínicas modeladas. Algunas urnas santamarianas piriformes de la muestra.

modeladas en el cuerpo, posee en la base por debajo de las asas dos suris-camélidos felinizados pintados similares a los motivos descritos anteriormente, en este caso flanqueando a un personaje humano (pieza ${ }^{\circ} 43$; Figura 6). La vasija procedente de Famabalasto, posee también en el cuerpo una cabeza de jaguar y en el lado opuesto una cola enroscada modelada (pieza n ${ }^{\circ} 39$; Márquez Miranda 1946: 171, Fig. 69.b).

Otra pieza con jaguares modelados de la muestra se encuentra en el museo de sitio del antiguo poblado de Quilmes (Tucumán). Variante de las urnas piriformes, con cuello recto y borde evertido, cuerpo globular y base no observable, posee dos apéndices modelados por encima de las asas representando cuerpo y cabeza de jaguares. El cuello tiene decoración en negro sobre baño rojo y el cuerpo, en negro sobre baño blanco. Acompañando esta división de colores la cabeza del jaguar está decorada en negro sobre rojo, mientras que el cuerpo del animal presenta decoración en negro sobre blanco (pieza no 41; ver Figura 6).

También forman parte de la muestra siete pucos globulares con apéndices modelados. Dos de ellos proceden de Amaicha, uno de Quilmes, uno de la provincia de Catamarca, uno de Tero (Cachi), otro de la región de Cachi y finalmente otro cuya procedencia es Argentina (Figura 7). Cuatro de estos pucos presentan una cabeza de jaguar y del lado opuesto también modelada en forma de espiral la cola del animal (piezas $n^{\circ} \mathrm{s} 42$, 46, 48 y 49; Figura 7). Otros dos presentan en lugar 


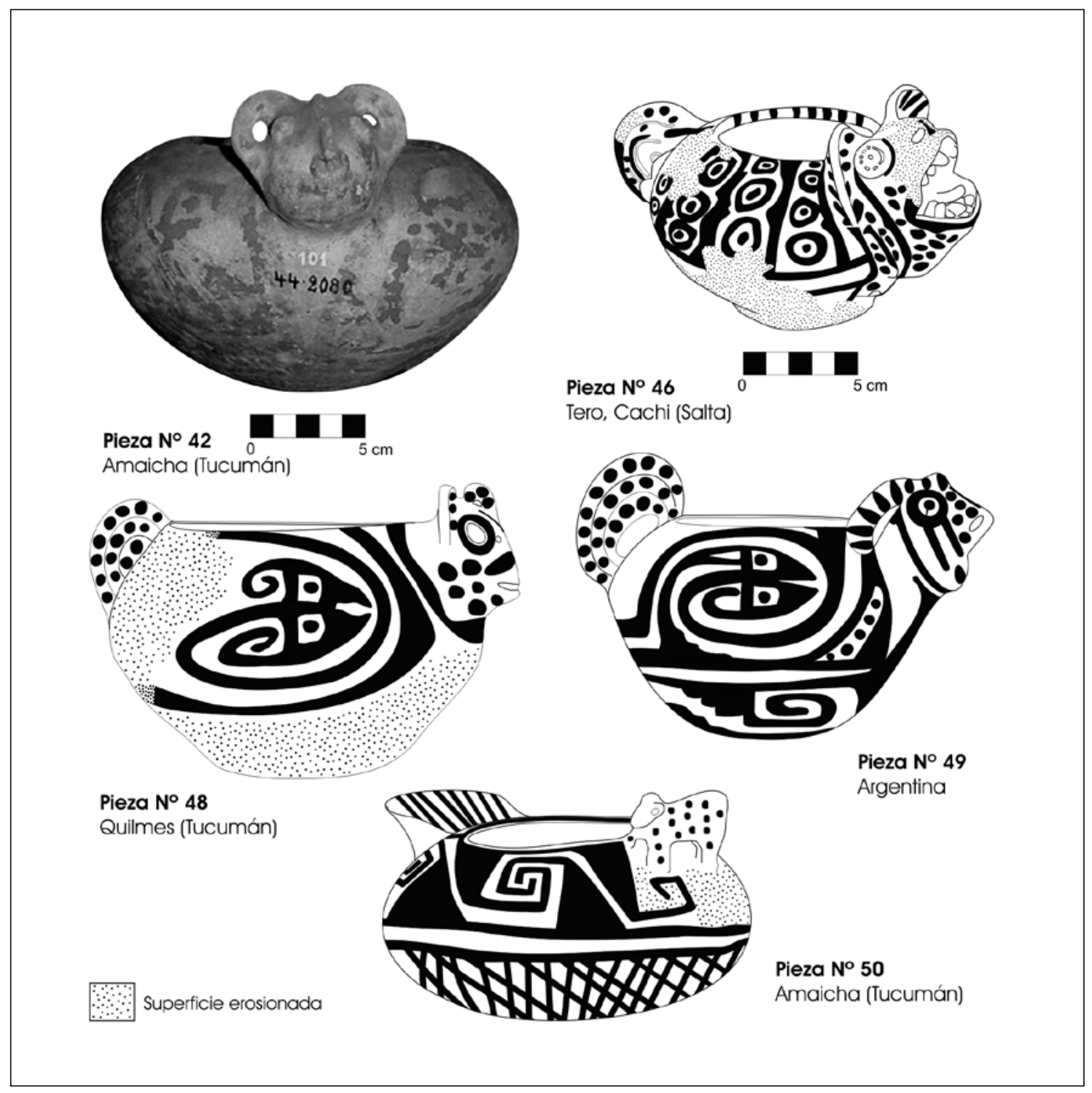

Figura 7. Representaciones felínicas modeladas. Algunos pucos santamarianos con apéndices modelados de la muestra.

de la cola los modelados típicos de los denominados vasos libatorios. ${ }^{18}$ Finalmente, el otro puco posee el cuerpo completo de un jaguar modelado sobre el borde y enfrentado el modelado libatorio (pieza n 50 ; Figura 7). Tomando como base la seriación propuesta por Perrotta y Podestá podemos decir que los pucos con asas zoomorfas y sin decoración interna podrían considerarse como pertenecientes a la penúltima fase,

\footnotetext{
${ }^{18}$ Forma de puco muy frecuente dentro de la variante calchaquí del estilo santamariano.
}

también correspondiente a los momentos finales del Tardío.

Por último tenemos una serie de apéndices modelados, fragmentos de una pieza mayor cuya forma no podemos observar. Sin embargo, los mismos son muy similares en cuanto a forma y decoración a los descritos en el análisis de las vasijas piriformes y los pucos con apéndices modelados. De los nueve apéndices, uno proviene de Santa María, uno de la región de Santa María, uno de San José, uno de Palo Seco (San José), 
uno de Anjuana, uno de Rincón Chico (Sitio 15) y tres de Fuerte Quemado (Figura 8). Si bien estas cabezas como dijimos son muy similares a los apéndices de pucos y urnas piriformes, también podrían tratarse de fragmentos de vasijas zoomorfas como aquella que incluimos en la muestra y que formaba parte del conjunto incaico recuperado en Casa Morada de La Paya, provincia de Salta. Hasta el momento esta pieza es la

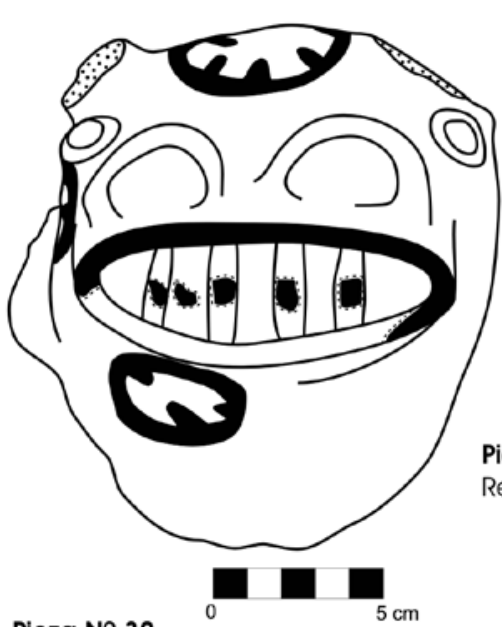

Pieza No 32

Palo Seco, San José (Catamarca)

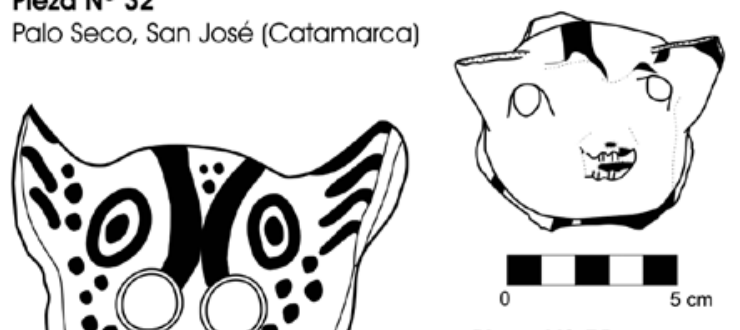

Pieza No 51

Rincón Chico -Sitio 15-

(Catamarca)

Pieza No 33

Región de Santa María
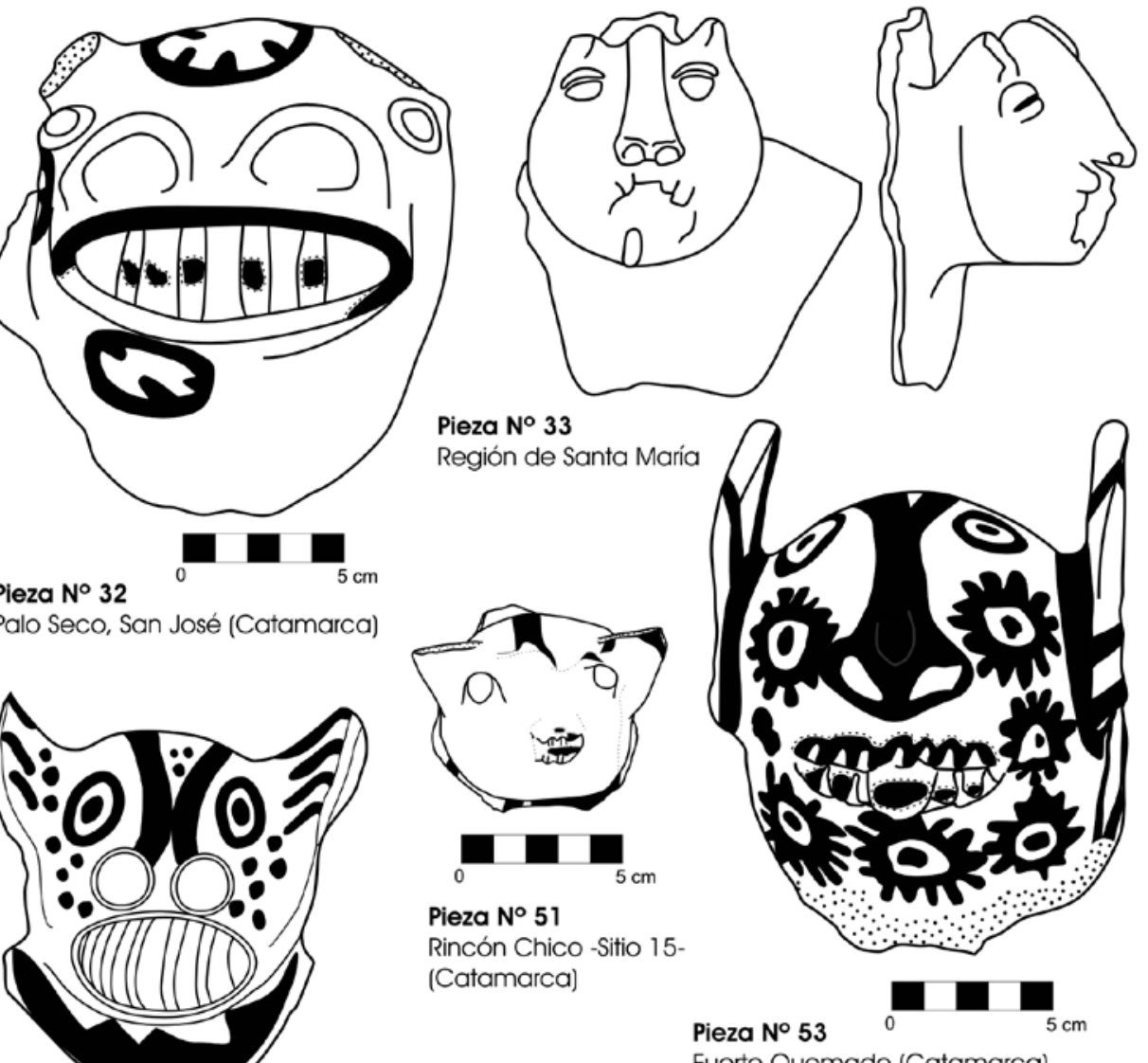

Pieza $\mathbf{N}^{\circ} \mathbf{4 0}$

Fuerte Quemado (Catamarca)

Anjuana (Tucumán)

Superficie erosionada

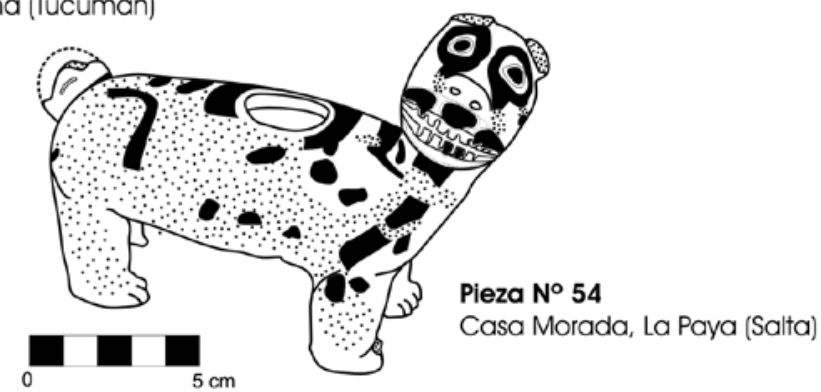

Figura 8. Representaciones felínicas modeladas. Algunos apéndices modelados de vasijas no observables y la vasija zoomorfa de Casa Morada (La Paya, Salta). 
única vasija zoomorfa felínica dentro del repertorio santamariano que se puede apreciar de forma completa (pieza no 54 ; Figura 8).

En las excavaciones realizadas por el propio Ambrosetti en La Paya (1907) se recuperaron en distintos sepulcros ${ }^{19}$ tres fragmentos de vasos libatorios con apéndices modelados representando jaguares. Estas vasijas no fueron incorporadas a la muestra, ya que no contamos con sus ilustraciones, sin embargo, por su descripción casi con seguridad se trata de pucos de estilo santamariano. Estos casos (junto con las piezas $\mathrm{n}^{\circ} \mathrm{s} 46$ y 52 de la muestra) están subrayando que la región de Cachi se destacaría por la presencia de representaciones felínicas aunque llamativamente sólo en su variante modelada sobre pucos.

En suma, podemos ver que el tema felínico en la iconografía santamariana está representado como jaguar en el caso de los modelados (salvo en algunas urnas piriformes donde el jaguar parece combinarse con murciélago) y, dentro del conjunto de las representaciones pintadas, en forma de atributos felínicos (básicamente de jaguar) otorgados a otras especies animales: al suri, a la serpiente, y menos frecuentemente al camélido o a la combinación suricamélido. En este sentido es interesante la vasija piriforme (pieza $n^{\circ} 43$; ver Figura 6) recuperada por el equipo de A. R. González en Corral Quemado (González 1974:59-62, Fig. 15), la cual, como ya mencionamos, además de los apéndices modelados en forma de cabezas de jaguares, presenta en la base motivos pintados de suris-camélidos felinizados. Es decir, en este único caso de la muestra en donde una misma vasija presenta motivos felínicos modelados y pintados, se mantienen las características diferenciales señaladas anteriormente: el jaguar en los modelados y los atributos de jaguar otorgados a otras especies animales en los motivos pintados.

\section{- Discusión}

El estudio de la iconografía santamariana nos llevó, por un lado, a centrarnos en el desarrollo cronológico del diseño,

\footnotetext{
19 Los sepulcros son: $n^{\circ} \mathrm{LV}, \mathrm{n}^{\circ} \mathrm{CXCI}$ y $\mathrm{n}^{\circ}$ CCXLVI (Ambrosetti 1907: $124,196-198,254-255)$.
}

lo que implicó retomar las seriaciones propuestas en los años 70 por Weber y Perrotta y Podestá cuyas tendencias temporales, en términos generales, fueron corroboradas por distintos estudios contextuales. Así, todas las piezas de estilo santamariano (fundamentalmente de la variante Yocavil) en donde pudimos encontrar representaciones de jaguares ya sea pintados o modelados, se restringen a los momentos finales del Período Tardío. Podemos hablar entonces de una desaparición del tema felínico en la iconografía de los primeros momentos del Tardío en Yocavil y de una reaparición hacia el final de dicho período en contemporaneidad con la presencia incaica en la región. Al mismo tiempo, el análisis realizado nos obliga a plantear una serie de discusiones relacionadas con el significado social de dichos cambios en el estilo que giran en torno a estas dos cuestiones básicas: la desaparición y la reaparición de la temática felínica en Yocavil.

Para abordar la primera cuestión tenemos que tener en cuenta la argumentación a la que hacíamos referencia en el comienzo de este trabajo en torno al "complejo felínico". El mismo siempre se asoció en la iconografía andina a situaciones vinculadas con la constitución y legitimación de relaciones de poder de tipo jerárquicas. En muchas sociedades del Noroeste Argentino que antecedieron a los desarrollos regionales del Período Tardío, el jaguar y el personaje humano con atributos felínicos fueron los grandes protagonistas de la iconografía religiosa. Así, la desaparición de la temática felínica (junto con otras muchas líneas de evidencia) estaría marcando una discontinuidad cultural entre las sociedades del Período Medio y del Período Tardío de la Subárea Valliserrana del Noroeste Argentino. En lo que se refiere a la organización sociopolítica, dicha discontinuidad podría estar ligada a la pérdida de eficacia de la ideología religiosa vinculada al "complejo felínico" para la constitución de las nuevas relaciones sociales. Las élites políticas religiosas del Tardío quizás intentaron desvincularse de la ideología del período anterior, o más precisamente de los referentes iconográficos vinculados a dicha ideología, ya que la misma se habría deslegitimado socialmente como resultado de la crisis social y política que creemos cierra el proceso histórico regional conocido como Aguada o de Integración Regional, iniciado alrededor de 60o DC. El felino desaparece entonces del repertorio iconográfico. La alfarería de las regiones en 
donde las distintas variantes del estilo Aguada tuvieron una presencia hegemónica como en el norte de La Rioja, Hualfín, Ambato, parece no retomar nunca más la iconografía felínica luego de que dicha cerámica deja de producirse. Los estilos Sanagasta, Abaucán y Hualfín están desvinculados de los temas felínicos. El caso de Belén es interesante, ya que, como veremos, conocemos una pieza con representación felínica, no obstante este elemento es de difícil discusión debido a que no está claro el desarrollo diacrónico del estilo Belén.

En la región de Yocavil los estilos posteriores a 1000 DC como San José, Shiquimil, Loma Rica y Santa María en su variante Tricolor tampoco presentan la temática felínica. Sin embargo, y a pesar de la ausencia de dichos motivos felínicos, luego de 400 años reaparecen en el estilo santamariano en asociación temporal con la ocupación incaica. Esta reaparición está vinculada a su vez con la incorporación de otros motivos que connotan violencia, como "guerreros" y cabezas cercenadas, aunque por el momento no hay forma de establecer claramente si estos cambios en la iconografía responden a factores ligados con la ocupación incaica en la región, o bien a situaciones locales previas que pudieron haberse acentuado durante la conquista incaica.

A. R. González ya en la década de 1970, al analizar la urna piriforme de Corral Quemado, interpreta los suris felinizados como una reminiscencia del estilo Aguada (1974:59-62). Actualmente, Nastriesboza un argumento similar al plantear que los rasgos felínicos en los motivos zoomorfos de las urnas santamarianas Fase IV (junto a otros motivos como los "guerreros") "pueden considerarse como indicadores de una reactualización de aspectos de la ideología del tiempo del Período de Integración [Regional]" (2006: 100), lo que habría implicado "una recuperación de narrativas de un tiempo pasado, en el marco de circunstancias sociales seguramente nuevas" (2006:187).

No obstante, también habría que pensar cómo pudo haberse mantenido en la memoria colectiva el repertorio iconográfico de Aguada y su significado durante 400 años luego del abandono, que aquí suponemos explícito, del "complejo felínico" como iconografía religiosa legitimante y legitimada y cuando la gran mayoría de los objetos portadores de esta ideología estaban enterrados o destruidos.
Lo cierto es que los motivos felínicos se incorporan a la iconografía santamariana en los momentos finales del Período Tardío en Yocavil. Como ya dijimos, lo que falta precisar es si se corresponden con la presencia incaica o surgen en momentos previos a la llegada de los incas. Sin embargo, las urnas fases $\mathrm{IV} y \mathrm{~V}$ con motivos felínicos se desarrollan plenamente durante la conquista incaica. Si dichos motivos en la iconografia santamariana tienen relación directa con la presencia de los incas en la región, lo más difícil será establecer si fueron expresión de la resistencia de las comunidades locales a través de la resignificación de un tema ya sea antiguo o nuevo o, por el contrario, constituyen la incorporación de un elemento de la ideología incaica al repertorio local como resultado de la dominación efectiva. Discutir estas posibilidades dependerá del avance en las investigaciones en torno a las estrategias de dominación incaica frente a las respuestas de las poblaciones locales en las distintas regiones del Noroeste Argentino y en Yocavil en particular.

Hemos registrado también la presencia del felino en otros estilos de la región contemporáneos a las vasijas santamarianas. Así, contamos con una escudilla globular Famabalasto Negro Grabado que posee una cabeza felínica y una protuberancia a manera de cola modelada en lados opuestos. Esta pieza procede de Fuerte Quemado (Bruch 1911: 77, Fig. 73. Museo de La Plata ${ }^{\circ} 87$ ) y a diferencia de los pucos santamarianos la cabeza del felino mira hacia arriba. Por otra parte, observamos una vasija de estilo Belén con un rostro blanco modelado combinado con un cuerpo de jaguar pintado a uno de sus costados (González y Zuviría 1999: 67, figura inferior). Estas dos vasijas con representaciones de felinos corresponden a estilos contemporáneos, al menos en parte, con la ocupación incaica de la región.

En este sentido, una mención especial merece el contexto de la vasija zoomorfa (pieza n ${ }^{\circ}$ 54; Figura 8) hallada en Casa Morada, recinto que los incas construyeron dentro del sitio tardío de La Paya. Esta vasija forma parte del conjunto de hallazgos excepcionales recuperados en dicha estructura (Boman 1991 [1908]; Ambrosetti 1902, 1907), entre los que se cuentan algunas piezas de clara filiación incaica como los dos kero de madera pintados y una pequeña olla de estilo inca cusqueño, junto con 
numerosas vasijas de estilo inca local (p.e., aribaloides). En este conjunto se registró también una cabeza de bronce con dos rostros felínicos (Ambrosetti 1902: 126-127, Fig. 10).Así, se pone de manifiesto la estrecha vinculación de estos felinos con la cultura material incaica.

De esta manera, la segunda cuestión aquí abordada, la reaparición del jaguar en momentos incaicos nos acerca finalmente a la relevancia simbólica del jaguary su representación dentro de la cultura incaica. La importancia de los felinos, el puma y el jaguar, en los mitos y ceremonias incaicos se desprende de diversas fuentes etnohistóricas y arqueológicas (Zuidema 1989; Farrington $2001 \mathrm{Ms}$ ). Aquí destacamos las representaciones felínicas, por cierto no muy frecuentes, presentes en su cerámica. Según Farrington (2001 Ms), las representaciones modeladas son las más numerosas dentro de este conjunto. Un ejemplo lo conformarían los pequeños apéndices de los aríbalos cuya estandarización no permite identificar, en la mayoría de los casos, si se trata de un jaguar o de un puma. Otro ejemplo serían los felinos modelados a manera de asas en distintas vasijas como pequeñas ollas y pucos. La gran mayoría de estas asas zoomorfas representan jaguares $y$, según este autor, la localización de dichos hallazgos es significativa debido a que provienen de lugares de importancia ceremonial como templos y palacios en Cusco, Tomebamba, Isla de la Luna, Chinchero, Ollantaytambo y Machu Picchu (2001 Ms: 19).

Resulta interesante, entonces, que algunas vasijas incaicas y santamarianas tardías compartan no sólo la temática felínica sino también el carácter naturalista de la representación de los felinos modelados siempre a manera de apéndices. En el caso de las piezas santamarianas, los modelados felínicos se observan en las vasijas piriformes, en ollas pequeñas de forma similar, en pucos, pero nunca en las urnas funerarias donde únicamente el jaguar aparece pintado como atributo del suri, el camélido y la serpiente. ${ }^{20}$ Estos elementos

20 La técnica de apéndices modelados está presente an algunas urnas Fase V, pero en este caso, siempre representando rostros humanos. muestran que será fructífero profundizar en el estudio del estilo incaico y su interacción con los estilos locales para discutir la presencia de la temática felínica en las vasijas de los últimos momentos del Período Tardío en Yocavil.

\section{Palabras finales}

Este trabajo planteó, por un lado, la sistematización de ciertas observaciones y, por otro, desarrolló algunas interrogantes en relación a la explicación de estas observaciones. El análisis de un corpus material de la iconografía cerámica santamariana nos permitió sostener que el tema felínico desaparece durante aproximadamente 400 años en Yocavil. A su vez desarrollamos una serie de ideas que le dan sentido al abandono y posterior reincorporación de dicho tema.

Los pasos a futuro implicarán no sólo ampliar la muestra cerámica sino también determinar si otros soportes materiales (p.e., arte rupestre, objetos de metal y de madera) pueden aportar datos para esta discusión. Al mismo tiempo se deberá precisar la cronología de las vasijas cerámicas que portan el motivo felínico, fundamentalmente en lo que se refiere a su posible contemporaneidad con la presencia incaica en la zona, para lo cual se procurará incorporar nuevos contextos fechados.

Finalmente, todos estos esfuerzos podrán aportar a la comprensión de los diversos y cambiantes significados que tuvo y aún tiene el jaguar en la historia de las comunidades andinas. En definitiva, este trabajo significó evocar antiguos regresos para descubrir una vez más que sólo se puede volver a lo nuevo.

Agradecimientos A Myriam Tarragó, Valeria Palamarczuk, Javier Nastri y a los dos evaluadores anónimos por la lectura y comentarios al manuscrito. También a Valeria Palamarczuk y a Marina Marchegiani por su aporte a la recopilación de la muestra. 


\section{REFERENCIAS CITADAS}

Ambrosetti, J. B., 1896-99. Notas de Arqueología Calchaquí. Boletín del Instituto Geográfico Argentino XVII-XX: varias series.

1902. El sepulcro de "La Paya" últimamente descubierto en los valles Calchaquíes (provincia de Salta). Anales del Museo Nacional de Buenos Aires, T VIII: 119-148.

Benson, E., 1974. A man and a feline in Mochica art. Studies in preColumbian art and archaeology 14: 1-31. Dumbarton Oaks, Trustees for Harvard University. Washington, D. C.

Boman, E., 1991 [1908]. Antigüedades de la región andina de la República Argentina y del Desierto de Atacama. Universidad Nacional de Jujuy, San Salvador de Jujuy.

BRuch, C., 1911. Arqueología de las provincias de Tucumán y Catamarca. Revista del Museo de La Plata 19. Biblioteca Centenaria, Buenos Aires.

Burger, R., 1992. Excavaciones en Chavín de Huantar. Pontificia Universidad Católica del Perú, Fondo Editorial, Lima.

Calderari, M. y V. Williams, 1991. Revaluación de los estilos cerámicos incaicos en el Noroeste Argentino. En Imperio Inka, actualización y perspectivas por registros arqueológicos y etnohistóricos, vol. II, Comenchingonia $\mathrm{n}^{\circ}$ especial: 75-95.

Castillo, L. J., 1993. Prácticas funerarias, poder e ideología en la sociedad Moche tardía: El Proyecto Arqueológico San José de Moro. Gaceta Arqueológica Andina VII (23): 67-82.

CAviglia, S., 1985 Ms. Las urnas para niños de los valles Yocavil y Calchaquí: Su reinterpretación sobre la base de un enfoque gestáltico. Trabajo final para el Seminario de Arqueología I, Facultad de Filosofía y Letras, Universidad de Buenos Aires.

Соок, А., 1994. Wari y Tiwanaku: Entre el estilo y la imagen. Pontificia Universidad Católica del Perú, Fondo Editorial, Lima.

FARRINGTON, I., 2001 Ms. The puma and the jaguar in inka archaeology of Cusco. Ponencia presentada en el XIV Congreso Nacional de Arqueología Argentina, Rosario.

FIADONE, A., 1999. Las fauces de la cultura La Aguada y su permanencia en la cultura Santa María como posible símbolo jerárquico. Actas del XII Congreso Nacional de Arqueología Argentina, vol. 2, pp. 92-100. La Plata.

Godelier, M., 1989. Lo ideal y lo material. Pensamiento, economías, sociedades. Taurus, Madrid. 1998. El enigma del don. Ediciones Paidós Ibérica, Madrid.
González, A. R., 1974. Arte, estructura y arqueología. Análisis de figuras duales y anatrópicas del Noroeste Argentino. Ediciones Nueva Visión, Buenos Aires.

1980. Arte precolombino de la Argentina. Una introducción a su historia cultural. Filmediciones Valero, Buenos Aires.

_ 1992. Las placas metálicas de los Andes del Sur. Contribución al estudio de las religiones precolombinas. Kommission Fur Allgemaine Und Vergleichende Archaeologie. Verlag Philipp Von Zabern, Mainz am Rhein.

1998. Cultura La Aguada; arqueología y diseños. Filmediciones Valero, Buenos Aires.

2004. La arqueología del Noroeste Argentino y las culturas formativas de la cuenca del Titicaca. Relaciones de la Sociedad Argentina de Antropología XXIX: 7-38.

GonzÁlez, A. R. y M. Baldini, 1991. Función y significado de un ceramio de la cultura de La Aguada. Ensayo de interpretación. Boletín del Museo Chileno de Arte Precolombino 5: 23-52.

GonzÁlez, A. R. y F. Zuviría, 1999. Colección Nicolás García Uriburu. Arte Precolombino. Artes Gráficas Ronor, Buenos Aires.

HAAs, J.y W. CReAmer, 2004. Cultural transformations in the Central Andean Late Archaic. En Andean archaeology, H. Silverman (Ed.), pp. 35-50. Blackwell Publishing, Londres.

Ibarra Grasso, D. E., 1971. Argentina indígena y prehistoria americana. Tipográfica Editora Argentina, Buenos Aires.

JoHANSSON, N., 1996. Burials and society: A study of social differentiation at the site of El Pichao, Northwestern Argentina, and in cemeteries dated to the Spanish Native Period. GOTARC, series B, Gothenburg Archaeological Theses $N^{\circ}$, Göteborg University, Gotemburgo.

Kusch, F., 1990. El concepto de humanidad en la alfarería prehispánica del Noroeste Argentino. Revista de Antropología V (9): 13-20.

Kusch, F. y C. ABAL, 2000. El jaguar de las cuatro zonas, estilo y subestilos de la Aguada. www.geocities.com/aguadaar/ (mayo 2006). Ponencias de la IV Mesa Redonda sobre la Cultura de La Aguada y su dispersión, San Pedro de Atacama.

KusCh, F.y M.VALKO, 1999. Los sistemas simbólicos y sus transformaciones. La Aguada después de La Aguada.Actas del XII Congreso Nacional de Arqueología Argentina, vol. 2, pp. 108-115. La Plata.

Lafone Quevedo, S., 1908. Tipos de alfarería de la región diaguitocalchaquí. Revista del Museo de La Plata XV: 295-396. 
Liberani, I. y R. Hernández, 1950 [1877]. Excursión arqueológica en los valles de Santa María, Catamarca. Universidad Nacional de Tucumán, Tucumán.

Marchegiani, M., 2004. La alfarería funeraria de Rincón Chico entre los siglos X y XVII DC (valle de Yocavil, Catamarca). Tesis de Licenciatura en Ciencias Antropológicas. Facultad de Filosofía y Letras, Universidad de Buenos Aires, Buenos Aires.

Márquez Miranda, F., 1936. La antigua provincia de los diaguitas. En Historia de la nación argentina, vol. 1, Junta de Historia y Numismática Americana (Ed.), pp. 277-350. Imprenta de la Universidad, Buenos Aires.

__ 1946. Los diaguitas. Revista del Museo de la Plata 3: 5-300.

Márquez Miranda, F. y E. M. Cigliano, 1957. Ensayo de una clasificación tipológico-cronológica de la cerámica santamariana. Notas del Museo de La Plata, T. XIX, Antropología 68: 1-27.

NASTRI, J., 2006. El simbolismo en la cerámica de las sociedades tardías de los valles calchaquíes (siglos XI-XVI). Tesis de Doctorado, Facultad de Filosofía y Letras, Universidad de Buenos Aires, Buenos Aires.

Nastri, J., G. Pratolongo, A. Reynoso y A. Vargas, 2004 Ms. Arqueología en la Sierra del Cajón: Poblados, corrales y pinturas. Ponencia presentada en el XV Congreso Nacional de Arqueología Argentina, Río Cuarto.

Perrotta, E. B.y C. Podestá, 1974 Ms. Seriación con valor cronológico de una colección de urnas y pucos santamarianos del valle de Yocavil. Ponencia presentada en el III Congreso Nacional de Arqueología Argentina, Salta.

1978. Contributions to the San José and Santa María Cultures, Northwest Argentina. En Advances in Andean archaeology, D. Browman (Ed.), pp. 525-551. Mouton, Nueva York.

PodestÁ, C.y E. B. PerRotTA, 1973. Relaciones entre culturas del Noroeste Argentino. San José y Santa María. Antiquitas XVII: 6-15.

Quiroga, A., 1994 [1929]. Folklore calchaquí. Colección Identidad Nacional, Secretaría de Cultura de la Nación en coproducción con Alberto Casares, Buenos Aires.

RafFino, R., G. RaviÑA, L. BALdinI y L. IACONA, 1979-1982. La expansión septentrional de la cultura La Aguada en el Noroeste Argentino. Cuadernos del Instituto Nacional de Antropología 9: 7-35.

Serrano, A., 1966. Manual de cerámica indígena. Assandri, Córdoba.
1967. Historia cultural del Tucumán prehispánico. Monografías XXVII. Instituto de Prehistoria y Arqueología, Diputación Provincial de Barcelona, Barcelona.

TARragó, M., 1995. Desarrollo regional en Yocavil. Una estrategia de investigación. Actas del XIII Congreso de Arqueología Chilena. Hombre y Desierto 9:225-236.

Tarragó, M. y M. C. Scattolin, 1999. La problemática del Período Formativo en el valle de Santa María. Actas del XII Congreso Nacional de Arqueología Argentina, vol. 1, pp. 142-153. La Plata.

Tarragó, M., S. Caviglia, M. Peralta Sanhuesa y J. Sosa, 1988 Ms. Los grupos cerámicos del poblado de Loma Rica de Shiquimil, Catamarca, Argentina. Ponencia presentada en el IX Congreso Nacional de Arqueología Argentina, Buenos Aires.

TARRAGÓ, M., L. GonzÁlez y J. NAStri, 1997. Las interacciones prehispánicas a través del estilo: El caso de la iconografía santamariana. Estudios Atacameños 14: 223-242.

Tartusi, M. y V. Núñez Regueiro, 2000. La presencia de Aguada en la provincia de Tucumán, Argentina. www.geocities.com/ aguadaar/ (mayo 2006). Ponencias de la IV Mesa Redonda sobre la Cultura de La Aguada y su dispersión. San Pedro de Atacama.

Velandia, C., 2005. Iconografía funeraria en la cultura arqueológica de Santa María, Argentina. Serie Monográfica 4. Investigaciones Arqueológicas y Paleontológicas del Cuaternario Pampeano de la Universidad del Centro de la Provincia de Buenos Aires, Universidad del Tolima, Ibagué.

WAGNER, E. y D. WAGNER, 1934. La civilización chaco-santiagueña y sus correlaciones con las del Viejo y Nuevo Mundo. Compañía Impresora Argentina, Buenos Aires.

Weber, R., 1978. A seriation for the Late Prehistoric Santa María Culture in Northwestern Argentina. Fieldiana Anthropology 68 (2): 49-98.

WiLliams, V., 2003. Nuevos datos sobre la prehistoria local en la quebrada de Tolombón. Provincia de Salta, Argentina. Anales Nueva Epoca "Local, regional, global: Prehistoria, protohistoria e historia en los valles calchaquies" 6:162-210. Göteborg University, Gotemburgo.

Zuidema, T., 1989. El león en la ciudad. Símbolos reales de transición en el Cusco. En Reyes y guerreros. Ensayos de cultura andina, M. Burga (Comp.), pp.306-383. Serie Grandes Estudios Andinos, FOMCIENCIAS, Lima. 